No. 1520

\title{
AQUAPORINS \\ IN INFECTION AND INFLAMMATION
}

\author{
ANGELIKA HOLM
}

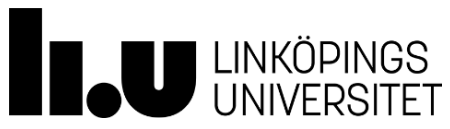

Division of Medical Microbiology

Department of Clinical and Experimental Medicine

Faculty of Medicine and Health Sciences

Linköping University

SE-581 85 


\section{About the cover:}

The front cover displays a human, blood-derived macrophage stained for aquaporin 9 .

During the course of the research underlying this thesis, Angelika Holm was enrolled in Forum Scientium, a multidisciplinary doctoral programme at Linköping University

Forum Scientium

Copyright (C) Angelika Holm

Division of Medical Microbiology

Department of Clinical and Experimental Medicine

Linköping University

SE-58185

Linköping

Paper I-III are reprinted with permission from the respective publishers.

ISBN: 978-91-7685-792-2

ISSN: 0345-0082

Printed by LiU-Tryck, Linköping, Sweden, 2016 
"Be brave, even if you're not, pretend to be. No one can tell the difference."

To that young, awkward, tall girl who dared to dream of something else, something more: You did it. 


\section{SUPERVISOR}

\section{Elena Vikström}

Department of Clinical and Experimental Medicine

Linköping University

Linköping

Sweden

\section{ASSISTANT SUPERVISORS}

\section{Karl-Eric Magnusson}

Department of Clinical and Experimental Medicine

Linköping University

Linköping

Sweden

\section{Vesa Loitto}

Department of Clinical and Experimental Medicine

Linköping University

Linköping

Sweden

\section{Jonas Wetterö}

Department of Clinical and Experimental Medicine

Linköping University

Linköping

Sweden

\section{FACULTY OPPONENT}

\section{Mikael Rhen}

Department of Microbiology

Karolinska Institutet

Stockholm

Sweden

\section{COMMITTEE BOARD}

\section{Ann-Beth Jonsson}

The Wenner-Gren Institute for Experimental Biology Stockholm University

Stockholm

Sweden

\section{Mårten Segelmark}

Department of Medicine and Health

Science

Linköping University

Linköping

Sweden

\section{Giannis Spyrou}

Department of Clinical and Experimental Medicine

Linköping University

Linköping

Sweden 
The ability of eukaryotic cells to change their shape and to migrate directionally is highly dependent on active volume regulation in cells building up tissues as well as in individual cells. Transmembrane fluxes of water via specialized water channels, called aquaporins (AQPs), facilitate the changes of volume and shape, which additionally require a complex interplay between the plasma membrane and the cytoskeleton. AQPs have been shown to be involved in the development of inflammatory processes and diseases. The aims of the studies underlying this thesis were to further elucidate the expression and function of AQPs in both bacterial and viral infections as well as in the inflammatory disease, microscopic colitis. For this, molecular techniques $\mathrm{qPCR}$, immunoblotting and live, holographic, confocal and super-resolution imaging were used.

When cells of the innate immune system encounter pathogens they need to respond and prepare for migration and phagocytosis and do so through volume regulatory processes. The Gramnegative bacterium Pseudomonas aeruginosa utilizes a small molecule-based communication system, called quorum sensing (QS) to control the production of its virulence factors and biofilms. We found that $P$. aeruginosa with a complete QS system elicits a stronger phagocytic response in human blood-derived macrophages compared to its lasI-/rhlI- mutant lacking the production of the QS molecules $N$-butyryl- $L$-homoserine lactone $\left(\mathrm{C}_{4}\right.$-HSL) and $N$-3-oxododecanoyl- $L$-homoserine lactone $\left(3 \mathrm{O}-\mathrm{C}_{12}-\mathrm{HSL}\right)$. Infection with $P$. aeruginosa further increases the expression of AQP9 and induces re-localisation of AQP9 to the front and trailing ends of macrophages. Moreover, the $3 \mathrm{O}-\mathrm{C}_{12}$-HSL alone elevates the expression of AQP9, redistribute the water channel to the front and rear ends and increases the cell area and volume of macrophages. Both infection with the wild type $P$. aeruginosa and the treatment with 3O$\mathrm{C}_{12}$-HSL change the nano-structural architecture of the AQP9 distribution in macrophages.

Viruses use the intracellular machinery of the invaded cells to produce and assemble new viral bodies. Intracellular AQPs are localised in a membranes of cellular organelles to regulate their function and morphology. $\mathrm{C} 3 \mathrm{H} 10 \mathrm{~T} 1 / 2$ fibroblasts transiently expressing green fluorescent protein (GFP)-AQP6 show a reduced expression of AQP6 after Hazara virus infection and an increased cell area. Overexpressing AQP6 in $\mathrm{C} 3 \mathrm{H} 10 \mathrm{~T} 1 / 2$ cells reduces the infectivity of Hazara virus indicating that AQP6 expression has a protective role in virus infections.

Ion and water channels in the epithelial cell lining tightly regulate the water homeostasis. In microscopic colitis (MC), patients suffer from severe watery diarrhoeas. For the first time, we have shown that the expression of AQP1, 8 and 11 and the sodium/hydrogen exchanger NHE1 are reduced in colonic biopsies from MC patients compared to healthy control individuals. Following treatment with the glucocorticoid budesonide the patients experienced a rapid recovery and we observed a restored or increased expression of the AQPs and NHE1 during treatment, suggesting a role for AQPs in the diarrhoeal mechanisms in MC.

Taken together, this thesis provides new evidence on the importance of water homeostasis regulation through AQPs during infections and inflammation and opens up a door for further investigations of roles for AQPs in inflammatory processes. 


\section{POPULÄRVETENSKAPLIG SAMMANFATTNING}

\section{Att kunna reglera cellers volym och vattenbalans genom vattenkanaler är viktigt vid infektion och vid inflammation}

Människan är i ständigt samröre med en mängd bakterier och virus. De flesta lever i symbios med oss medan andra, patogener, orsakar sjukdom. För att försvara oss mot dessa har vi utvecklat olika skydd. Vår hud och ett tätt lager av epitelceller i mun, mage och tarm utgör vårt yttre försvar mot inkräktare. Om det sker en överträdelse och mikroberna kommer in har vi ett välutvecklat immunförsvar, som strävar efter att ta hand om och oskadliggöra patogenerna. Detta kräver att cellerna kan ändra och reglera sin volym och röra sig mot platsen för infektionen för att påbörja inflammationsprocessen i ett försök att tillintetgöra inkräktarna. För att snabbt ändra sin volym och möjliggöra cellrörelse krävs en komplex interaktion mellan cellens yttre membran och dess inre stödstrukturer, cytoskelettet, som tillsammans reglerar cellens form. I dessa processer använder sig cellen även av vatten som genom speciella kanalproteiner, akvaporiner, transporteras in och ut ur cellen och möjliggör för cellen att forma utskott och röra sig. En störning av dessa akvaporiner orsakar problem med vattenbalansen både inuti och utanför cellen. Sådana störningar utnyttjas troligtvis av olika mikrober. I denna avhandling undersökte vi hur akvaporiner påverkas under både bakteriella och virala infektioner samt i den inflammatoriska tarmsjukdomen mikroskopisk kolit.

I första försvarslinjen deltar celler som makrofager och neutrofiler. Deras främsta uppgift är att oskadliggöra bakterier och virusinfekterade celler genom att ta upp och förstöra dem, i en process kallad fagocytos. Pseudomonas aeruginosa är en opportunistisk bakterie som kan ge både akuta och kroniska infektioner i urin- och luftvägarna och i sår hos främst personer med nedsatt immunförsvar. Pseudomonas använder sig av ett kommunikationssystem av små molekyler som kallas quorum sensing. Bakterien nyttjar det för att producera olika hjälpämnen som förbättrar deras förmåga till delning och infektion. Samtidigt har vårt immunförsvar lärt sig känna igen quorum sensing-molekylerna för att detektera infektion. Två viktiga kommunikationsmolekyler är $\mathrm{C}_{4}-\mathrm{HSL}$ och 3O-C $12-\mathrm{HSL}$. När vi infekterade makrofager med $P$. aeruginosa kunde vi se att bakterier med ett komplett quorum sensing-system fagocyterades bättre än en mutant som saknade $\mathrm{C}_{4}-\mathrm{HSL}$ och $3 \mathrm{O}-\mathrm{C}_{12}$-HSL. Infektion med $P$. aeruginosa ökade också mängden akvaporin 9 (AQP9), som är den vanligaste vattenkanalen i humana makrofager. Vi kunde även se att cellerna blev större och längre samt att infektionen fördelade AQP9 till främre och bakre delen av cellerna. Bakterier med ett fullt fungerande kommunikationssystem hade en starkare effekt än mutanten. Förändringar i storlek och en omfördelning av AQP9 kan tyda på att cellerna förbereder sig för cellrörelse och fagocytos. För att vidare se hur quorum sensing påverkar makrofager stimulerade vi makrofager med enbart $3 \mathrm{O}-\mathrm{C}_{12}$-HSL. Stimuleringen ledde till att makrofagerna ökade sin area och sin volym, mängden AQP9 ökade och vattenkanalen distribuerades om till främre och bakre delen av cellerna.

Viruset som orsakar Krim-Kongo blödarfeber sprids med fästingar och orsakar svår sjukdom med hög dödlig utgång. Det är mycket smittsamt och för att kunna arbeta med det krävs särskilda laboratorier med hög säkerhet. Hazaraviruset är besläktat med Krim-Kongo-viruset och liknar det strukturellt, men orsakar inte sjukdom hos människa. Detta gör Hazara till ett 
passande virus för att använda när man vill studera Krim-Kongo-viruset enbart med tillgång till ett vanligt mikrobiologisk laboratorium. Virus kan inte föröka sig själva utan använder sig av en värdcells intracellulära maskineri för att producera nya viruspartiklar. Akvaporiner finns inte bara i cellers yttersta membran utan även i membran som bygger upp olika strukturer inuti cellen. Akvaporin 6 (AQP6) är en intracellulär vattenkanal som finns i olika vesiklar (membranblåsor), och kan förutom vatten även transportera laddade joner. Den aktiveras också vid lågt $\mathrm{pH}$, som utgör en varningssignal för cellen. I ett försök att se om vattenkanaler påverkas av virusinfektion fick vi celler att producera AQP6 och infekterade dem sedan med Hazaravirus. Vi kunde se att infektion ledde till att mängden av AQP6 minskade i infekterade celler samtidigt som deras yta blev större. Men när cellerna uttryckte mycket AQP6 såg vi färre viruspartiklar i cellerna, vilket tyder på att det var svårare för viruset att infektera dessa celler. Det verkar således som att AQP6 kan ha en skyddande roll i virusinfektioner och det är därför viruset minskar mängden AQP6 när det infekterar celler.

I tarmen skyddar ett tätt lager av epitelceller oss mot alla de miljarder bakterier som ingår i vår normalflora. Tarmepitelet har till uppgift att stänga ute mikrober men måste samtidigt vara genomsläppligt för att möjliggöra upptag av näringsämnen och för att utsöndra vätska och slaggprodukter. Vattenbalansen är mycket viktig i tarmen. Vid sjukdomen mikroskopisk kolit drabbas patienter av inflammation i tarmen vilket leder till kraftiga, vattniga diarréer. Vid behandling med kortison, budesonid, blir patienterna bättre och de vattniga diarréerna avtar. De underliggande mekanismerna om hur sjukdomen uppstår eller hur behandlingen fungerar är ännu okänt. Här visar vi för första gången att patienter med mikroskopisk kolit har färre akvaporiner i tjocktarmens epitel jämfört med friska personer. Dessutom kan vi se att under behandling med budesonid återställs antalet av flera av vattenkanalerna. Detta visar att mängden av akvaporiner spelar en viktig roll under sjukdomsförloppet av mikroskopisk kolit. Vattenkanalerna är sannolikt en del av orsaken till de vattniga diarréerna och en återställning av dessa återskapar vattenbalansen i tarmen och skulle kunna vara den huvudsakliga effekten av läkemedlet budesonid vid behandling av mikroskopisk kolit.

Sammanfattningsvis visar vi i denna avhandling att både infektion med $P$. aeruginosa och Hazaravirus påverkar cellers volym och area samt antalet och fördelningen av akvaporiner i infekterade celler. Dessutom är mängden av akvaporiner förändrat i den inflammatoriska tarmsjukdomen mikroskopisk kolit, där kanalerna troligtvis påverkar vattenbalansen $\mathrm{i}$ tarmen och orsakar diarrén. Behandling med budesonid återställer mängden akvaporiner och förbättrar symptomen hos patienterna. Sammantaget stärker dessa resultat hypotesen att akvaporiner fyller en viktig funktion vid olika infektioner och i inflammationsprocessen. 


\section{LIST OF PAPERS}

Paper I

ANGELIKA HOLM, Thommie Karlsson, Elena Vikström

Pseudomonas aeruginosa lasI/rhlI quorum sensing genes promote phagocytosis and aquaporin 9 redistribution to the leading and trailing regions in macrophages

Frontiers in Microbiology- Microbial Immunology 2015, Sep 3;6:915

DOI: $10.3389 /$ fmicb.2015.00915

\section{Paper II}

ANGELIKA HOLM, Karl-Eric Magnusson, Elena Vikström

Pseudomonas aeruginosa $\mathbf{N - 3 - o x 0 - d o d e c a n o y l - h o m o s e r i n e ~ l a c t o n e ~ e l i c i t s ~ c h a n g e s ~ i n ~ c e l l ~}$ volume, morphology and AQP9 characteristics in macrophages

Frontiers in Cellular and Infection Microbiology, 2016

DOI:10.3389/fcimb.2016.00032

\section{Paper III}

Andrea Molinas, Ali Mirazimi, ANGELIKA HOLM, Vesa M. Loitto, Karl-Eric Magnusson, Elena Vikström

Protective role of host aquaporin 6 against Hazara virus, a model for Crimean-Congo hemorrhagic fever virus infection

FEMS Microbiol Lett. 2016 Mar 13. PMID: 26976854

DOI: 10.1093/femsle/fnw058

\section{Paper IV}

ANGELIKA HOLM, Adrian Mancebo-Gomez, Vesa Loitto, Elena Vikström, Andreas Münch Aquaporin expression and localisation in colonic biopsies from collagenous colitis patients

Manuscript 


\section{ABBREVATIONS}

$3 \mathrm{O}-\mathrm{C}_{12}$-HSL - N-3-oxo-dodecanoyl- $L$-homoserine lactone

ABPs - Actin-binding proteins

$\mathrm{AHL}-N$-acylhomoserine lactone

$\mathrm{AI}$ - autoinducer

$\mathrm{AQP} / \mathrm{AQPs}$ - aquaporin(s)

Arp 2/3 - actin-related protein $2 / 3$

BSA - bovine serum albumin

$\mathrm{C}_{4}$-HSL $-N$-butyryl- $L$-homoserine lactone

CC- collagenous colitis

DAMPS - damage-/danger-associated molecular patterns

DC - dendritic cell

GFP - green fluorescent protein

$\mathrm{H}_{2} \mathrm{O}_{2}$ - hydrogen peroxide

HSCs - hematopoietic stem cell

ICAM - intercellular adhesion molecule

iNOS - inducible nitric oxide synthase

IFN - interferons

KRG - Krebs-Ringer Glucose buffer

LC - lymphocytic colitis

$\mathrm{MC}-$ microscopic colitis

NFкB - nuclear factor kappa-light-chain-enhancer of activated B cells

$\mathrm{NO}$ - nitric oxide

PAMPS - pathogen-associated molecular patterns

PBS - phosphate-buffered saline

PEST - penicillin + streptomycin

PMN - polymorphonuclear leukocyte

PRR - pattern recognition receptors

QS - quorum sensing

ROS - reactive oxygen species

$\mathrm{TNF}$ - tumour necrosis factor

VCAM - vascular cellular adhesion molecule

WASP - Wiskott-Aldrich syndrome protein 


\section{TABLE OF CONTENT}

ABSTRACT

POPULÄRVETENSKAPLIG SAMMANFATTNING iii

Att kunna reglera cellers volym och vattenbalans genom vattenkanaler är viktigt vid infektion och vid inflammation iii

LIST OF PAPERS $\quad$ V

ABBREVIATIONS vii

TABLE OF CONTENT viii

$\begin{array}{lr}\text { INTRODUCTION } & 1\end{array}$

Host-pathogen interactions 1

Water fluxes and volume regulation 3

Aquaporins $\quad 4$

Cell migration 6

Actin and its partners 6

$\begin{array}{ll}\text { Aquaporins in cell migration } & 7\end{array}$

$\begin{array}{ll}\text { Macrophages and the innate immune system } & 7\end{array}$

Aquaporins in the immune system 9

$\begin{array}{ll}\text { Bacteria } & 9\end{array}$

$\begin{array}{ll}\text { Virulence factors } & 10\end{array}$

$\begin{array}{ll}\text { Lipopolysaccharide and aquaporins } & 11\end{array}$

$\begin{array}{ll}\text { Quorum sensing } & 12\end{array}$

$\begin{array}{ll}\text { Quorum sensing and the host } & 13\end{array}$

$\begin{array}{ll}\text { Virus } & 14\end{array}$

$\begin{array}{ll}\text { Viruses and aquaporins } & 15\end{array}$

$\begin{array}{ll}\text { Water homeostasis in the intestine } & 15\end{array}$

$\begin{array}{ll}\text { Aquaporins in gastrointestinal homeostasis and diarrhoea } & 16\end{array}$

$\begin{array}{ll}\text { Inflammatory bowel disease and microscopic colitis } & 16\end{array}$

$\begin{array}{ll}\text { Aquaporins in inflammatory bowel diseases } & 17\end{array}$ 
$\begin{array}{ll}\text { Ethical considerations } & 21\end{array}$

$\begin{array}{ll}\text { Cells and cell culture } & 21\end{array}$

Isolation and culture of human primary monocyte-derived macrophages 21

GFP-AQP6 expressing C3H10T1/2 chimeric cells 22

$\begin{array}{ll}\text { Bacteria } & 22\end{array}$

$\begin{array}{ll}\text { AHL synthesis } & 22\end{array}$

$\begin{array}{ll}\text { Treatment with } \mathrm{AHL} \text { and aquaporin inhibitors } & 22\end{array}$

Bacterial infection and treatment with AHLs 23

$\begin{array}{ll}\text { Virus } & 23\end{array}$

$\begin{array}{ll}\text { Virus infection } & 23\end{array}$

Determination of virus by immunofluorescent assay 23

$\begin{array}{ll}\text { Visualization } & 24\end{array}$

$\begin{array}{ll}\text { Live cell imaging } & 24\end{array}$

2D imaging 24

3D holographic imaging 24

Epifluorescence imaging of living cells with spinning disc confocal microscopy 24

$\begin{array}{ll}\text { Confocal and super resolution imaging } & 25\end{array}$

$\begin{array}{ll}\text { Laser scanning confocal microscopy (LSCM) } & 25\end{array}$

$\begin{array}{ll}\text { Phagocytosis assay } & 25\end{array}$

$\begin{array}{ll}\text { Super-resolution microscopy } & 26\end{array}$

$\begin{array}{ll}\text { Structured illumination microscopy } & 26\end{array}$

Stimulated emission depletion microscopy 26

$\begin{array}{ll}\text { Image analyses } & 27\end{array}$

$\begin{array}{ll}\text { Quantitative PCR (qPCR) } & 27\end{array}$ 
mRNA array analysis

Preparation of total cell lysate, SDS-PAGE and immunoblotting

Patient group

Immunohistochemistry

Haematoxylin/eosin staining

Statistical methods and analyses

Paper I

"Pseudomonas aeruginosa lasl/rhll quorum sensing genes promotes phagocytosis and AQP9 redistribution to the leading and trailing regions in macrophages"

Paper II

"Pseudomonas aeruginosa N-3-oxo-dodecanoyl-homoserine lactone elicits changes in cell volume, morphology and AQP9 characteristics in macrophages"

Paper III

"Protective role of host aquaporin 6 against Hazara virus, a model for Crimean-Congo haemorrhagic fever virus infection"

Paper IV

"Aquaporin expression and localisation in colonic biopsies from collagenous colitis patients" 
"Nothing in life is to be feared, it is only to be understood.

Now is the time to understand more, so that we may fear less." Marie Curie 


\section{INTRODUCTION}

All living organisms strive to maintain homeostasis. Originating from the Greek word "homoios" meaning same and "stasis", stable, homeostasis refers to a stable condition necessary for survival and growth. Cells, tissues and the body constantly regulate their internal environments to external changes. Swelling of cells and tissue in combination with excess extracellular fluids (oedema) indicate a disturbance in the homeostasis and are common denominators of inflammation. Swelling (tumor) was described already in the $1^{\text {st }}$ century by the Roman medical writer Aulus Cornelius Celsus in his books De medicina, as one of the four cardinal signs of inflammation. The others being redness (rubor), heat (calor) and pain (dolor). Inflammation is the body's response to harmful stimuli. Too weak response and the stimuli, such as bacteria will cause extensive damage and disease, but a too strong response can also lead to tissue damage and the development of a chronic inflammatory state. Thus resolving inflammation is crucial to retain homeostasis.

Infections are common causes to inflammation. Humans live in a multifaceted relationship with microbes and are at war with the microbial world. Normally we are in symbiosis with our normal flora while at the same time we need to be able to fight off pathogens. The skin and the internal mucosal surfaces covering the outside and the inside of the human body are natural barriers for pathogens. When the barriers fail, the damage as well as the invading microbes will trigger the immune system. At large the response can be described by four Rs: recognize, remove, regulate and remember. The immune system recognizes foreign agents or non-selfmatter and cells, removes them by various effector functions and regulates both the pathogen and the immune response to protect the body as well as remembers the pathogen so that the intruder will be stopped from infecting again.

The status of the host, the characteristics of the microbe, the ability to recognise and respond appropriately are some of many factors influencing the initiation, development and outcome of infections and inflammation (Fig.1).

\section{Host-pathogen interactions}

Our immune system learns and develops in close interplay with the microbes that we are exposed to. Increasing evidence suggests that exposure and non-exposure of different microbes are associated with a diverse set of diseases, e.g. allergy development, inflammatory diseases and cancer $[1,2]$. Life is a constant struggle for survival, not only for us but also for the microbes. They use a broad arsenal of protection and weapons to secure their existence. In the process of increasing their chances of survival bacteria have developed a communication system, called quorum sensing (QS). This allow them to work and function as a multicellular organism on population level. Bacteria, like Pseudomonas aeruginosa uses this to create protecting biofilms which allow them to be sheltered and defended against e.g. the immune system. Some bacterial species, like Escherichia coli lack the ability to produce a broad array 


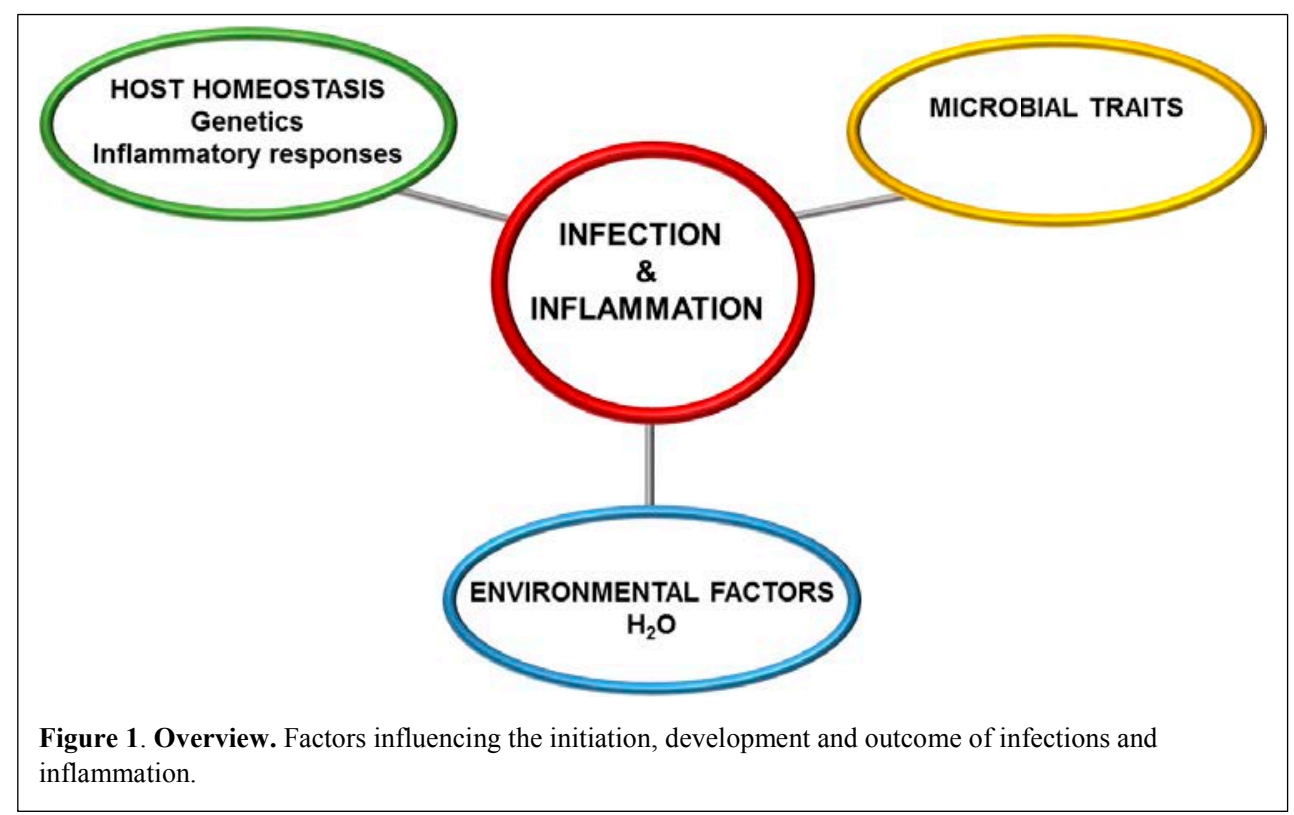

of QS-molecules but have learned to listen in and be affected by the communication molecules secreted by other bacterial species [3]. Human cells have also learned to react to this molecular communication. Immune cells become stimulated and move towards the site of the bacteria when sensing the QS, i.e. a movement of cells towards an increasing gradient of stimuli (chemotaxis) [4]. QS-molecules also stimulate phagocytosis, where the stimulation is concentration-dependent. In proximity to biofilms the concentrations of the molecules are high which leads to an inhibition of chemotaxis and phagocytosis in the immune cells, protecting the bacteria from elimination $[5,6]$.

Regarding viruses, they utilize host cells to replicate and multiply. Virus infections initiate the production of interferons (IFNs), which are cytokines that recruit immune cells to the site of the infection and trigger immune responses to eliminate the infection. Viruses have developed different ways to counteract these actions by e.g. manipulating host cells to produce interleukin10 (IL-10). IL-10 suppress pro-inflammatory cytokines and modulate behaviours and response of immune cells [7].

Studying the host-pathogen interplay can give us insights in how the immune system and hostpathogen communication work together and may provide new means to tackle infections and inflammation. Infections are one of the most common causes of acute death in the world and in the medical ward. Ever since penicillin was discovered by Alexander Fleming in 1928 we have been able to fight and restrain bacterial infections with antibiotics, saving millions of lives and decreasing suffering. Antibiotic resistance is an increasing problem with rapid development of antibiotic resistant bacterial strains due to overuse of antibiotics and through the natural process of bacterial evolution. Therefore currently easy to handle infections might become severe and deadly. Common infections like pneumoniae could without antibiotic treatment quickly lead to a lethal outcome. By studying the microbial world and the interactions between host and 
pathogen new ways and insights on how to fight infections can come available. For example disrupting the bacterial QS system is one proposed way to explore in the search for new ways to treat infections and eliminate bacteria.

\section{Water fluxes and volume regulation}

Swelling of cells have long been seen as a hallmark of inflammation and indicate an imbalance in the water-homeostasis. Cells utilize water to regulate their volume. The adult human body consist of approximately $60 \%$ of water, thus making water the most abundant molecule in the body and it is needed to be under strict control to retain water-homeostasis. Approximately $50 \%$ of all body water is contained inside the cells. All cells are enclosed by the plasma membrane. The plasma membrane is a lipid bilayer and act as a barrier for the cells to the surrounding environment. The cells regulates the passage of charged ions and hydrophilic solutes via membrane-bound transporters and channel proteins. The lipid bilayers is practically impermeable to water and even though water can diffuse through cell membranes and sometimes by co-transport with ions or other solutes [8] the cells do so more efficiently through water channels, so called aquaporins (AQPs) [9]. The AQPs allow the passage of water molecules in a bi-directional manner over the lipid bilayer.

The body as a whole controls water homeostasis primarily by uptake through the intestine and colon and the excretion via the kidneys and skin. But the ability to regulate volume, shape and migration is essential for cells in all tissues and in various physiological processes. Water through AQPs regulate a cell's size, volume and different chemical reactions in a complex interplay with different ion-channels and the cytoskeleton. It is believed that the flux of water through AQPs occurs primarily via osmosis [10]. The osmolarity of the extracellular fluid in the body is normally around $280-300 \mathrm{mOsm} / \mathrm{kg} \mathrm{H}_{2} \mathrm{O}$ normally. When cells are exposed to low osmotic pressure, e.g. hypotonic solutions they respond by a rapid volume increase by influx of water. If the exposure is prolonged the cells will eventually decrease their volume again through regulatory volume decrease (RVD). Ion and water fluxes, thus re-adjust the cell volume. On the other hand, when subjected to an increased osmotic pressure, e.g. hypertonic solutions the cells will shrink and a shrinkage will again be followed by a regulatory volume increase (RVI) if the exposure is prolonged. Thus, by regulating water and ion fluxes over the plasma membrane the cells can compensate for osmolarity changes in their surroundings and obtain water homeostasis.

There is increasing evidence of the importance of volume regulating events in both health and disease [11-13]. For instance, it has been reported that blebbing or membrane ballooning occur in spreading platelets and that it is depended on ion and water fluxes [14]. Immune cells depend on water influxes in their directed migration $[15,16]$ and epithelial cells utilize swelling during wound healing [17]. 


\section{Aquaporins}

The aquaporin (AQPs) water channels are critical components in the regard to volume regulation and water homeostasis. All the 13 different mammalian AQPs known today are involved in numerous cellular events, both during normal and pathological condition $[11,18]$.

AQPs were first described by Professor Peter Agre in 1992 [9], a discovery that rendered him the Nobel Prize in Chemistry in 2003. AQPs are membrane-bound water channels with a molecular weight around $30 \mathrm{kDa}$. Each monomer consists of six membrane-spanning helical domains forming a bidirectional pore and two helical segments that embrace the extra- and intracellular vestibules respectively. The monomers come together and form tetramers in the plasma membrane. There are 13 different mammalian AQPs, being divided into three main groups; water selective AQPs (AQP0, 1, 2, 4, 5 and 8), aquaglyceroporins (AQP3, 7, 9 and 10) and S-aquaporins (super- or subcellular AQP, AQP11 and 12). AQP6 can be included into the S-aquaporin-group but has also been shown to transport selected ions. The selectivity of the channels is dependent on the pore size. The water-selective AQPs have a pore size of $\sim 2.8 \AA$ and a water molecule is about $2.75 \AA$. The highly preserved asparagine-proline-alanine (NPA)motif prevents ions to pass the channel [19] and the constrictive site where an aromatic/arginine region re-positions the water molecules, letting $\mathrm{H}_{2} \mathrm{O}$ pass while excluding protons [20]. AQP11 and AQP12 are however exceptions to the presence of the conserved NPA-motif [21, 22]. Under normal physiological conditions the body utilizes the AQPs for diverse organ and cellular events. The kidney uses AQPs to concentrate urine, the salivary glands uses AQP5 in the secretion of saliva, the liver uses AQP9 for glycogenesis [23, 24].

Under pathological conditions there is increasing evidence for an involvement of AQPs. For example, AQP4 is widely expressed in the brain and is believed to be involved in the water homeostasis of the brain over the blood-brain barrier but has also been shown to be involved in synaptic plasticity and memory development [25]. In the development and process of brain oedema however AQP4 over-expression seems to worsen the outcome [26, 27]. There is increasing data showing an important role for AQPs in the development of tumours and cancer metastasis [28]. In AQP1 knockout mice there is an impairment of angiogenesis, the process of developing new blood vessels, which reduce tumour growth [29]. This is believed to be because of a reduced ability for the cells to migrate. There is now also quite extensive work showing the importance of AQPs in cell migration $[11,13,17,18,30,31]$ and hence also in cancer development and metastasis $[18,32,33]$. The aquaglyceroporins can act as metalloid channels as reviewed in [34], and AQP7 and AQP9 have also been shown to be permeable to the heavymetal arsenic [35], which is a mechanism believed to be involved in the process of arsenic poisoning. The AQPs have also been hypothesized to be involved in the cellular death process of apoptosis [36]. AQP8 and an isoform of AQP9 have been found in mitochondrial membranes and are believed to be involved in the volume regulation and metabolic process of mitochondria respectively.

Regarding their role in different pathologies the AQPs are being investigated as potential drug targets, primarily by blocking the fluxes of water. The AQPs can, for instance, be inhibited with mercury-based compounds [37] with the exception of AQP6 that is stimulated by mercury [38]. Jelen et al., screened a small molecule library in the search for inhibitors of AQP9 and found 
the compound HTS13286 that specifically inhibits glycerol transport by AQP9 in hepatocytes [39]. The inhibitor has also been used to impair membrane protrusion and bleb formation in AQP9 expressing cells [40]. The gold-based compound Auphen has been shown to elicit an inhibitory effect on AQP3 [41]. An inhibitor of AQP1 called AqB013 has shown promising effects on the migration and invasion of colon cancer cells in vitro [42].

The function of AQPs is controlled by expression and perhaps foremost by translocation to the cell membranes [43]. The AQPs can rapidly and reversibly translocate to the plasma membrane from intracellular vesicles. They do so in response to a wide range of stimuli, e.g. vasopressin (AQP2 in the kidneys), histamine (AQP4 in gastric cells) and hypo- and hypertonicity (AQP3 in keratinocytes and AQP9 in human neutrophils respectively).

In this doctoral thesis, the main focus, specifically in the first part, has been AQP9. AQP9 is the predominant $\mathrm{AQP}$ in human immune cells but is also expressed in for instance the liver, adipose tissue, the brain and the testis. Among the aquaglyceroporins, AQP9 is one of the most promiscuous AQPs. In addition to water, it is permeable to urea, nucleosides, lactate and glycerol $[44,45]$. When expressing AQP9 in oocytes the water permeability increased 30 -fold [46]. With its broad permeability spectra and wide range expression, AQP9 has been shown to be involved in numerous physiological functions. Through its $\mathrm{C}$-terminal region AQP9 can bind to PSD95-Discs large-ZO1 (PDZ) domains on other proteins and it is probably through this it interacts with numerous binding partners, like the cystic fibrosis transmembrane conductance regulator (CFTR) [47]. AQP9 has also been shown to be involved in hepatic glycerol metabolism and adipocyte lipogenesis [23, 24]. The metabolite glycerol is important as a substrate for de novo synthesis of triacylglycerol and glucose. Our group has also shown how AQP9 is involved in the control of cell shape and motility of both human leukocytes and epithelial cells [15-17, 48, 49]. In chronic inflammatory diseases, like Rheumatoid arthritis (RA) and psoriasis, the expression of AQP9 is increased and it has thus been proposed to be a potential marker of chronic inflammation [50]. The AQP9 gene holds a putative glucocorticoid binding motif [45] linking it to possible transcriptional responses in inflammatory reactions. The expression has also been shown to be affected by oestrogen [51].

AQP6 is the focus of the third paper in this thesis. It is an intracellular AQP present in cytoplasmic vesicles and membranes. It is permeable to water but has also been shown to be able to transport ions $[38,52]$, the latter capability being activated by low $\mathrm{pH}$. AQP6 is not like most AQPs inhibited by mercury but rather stimulated with associated increased ion fluxes [38, 53]. It is expressed in various types of tissue, including kidney, mucosal epithelia and platelets $[52,54-56]$. AQP6 is believed to be involved in the sorting of vesicles in the cell $[52,55]$. 


\section{Cell migration}

In inflammation and infection the volume and shape regulation of cells is highly important in the recognition of cell damage, cell motility, as well as in phagocytosis [17, 48, 57-59]. Cell migration is a prerequisite for human life and development and it is an essential part of the human immune response. Neutrophils and monocytes migrate to the site of infection, DC's migrate to lymph nodes to present antigens for the adaptive immune system that then migrates out to the site of infection.

The basis of cell migration is the ability of cells to react and respond to external cues. In directional migration, cells move towards extracellular stimuli, e.g. soluble gradient of a substance such as LPS, in a process called chemotaxis. In order to migrate the cells must be able to change their volume and shape. The process of migration could simply be described as a repetitive cycle of protrusion, adhesion and retraction. The cell polarizes in the direction of migration by extending a wide thin lamellipodium and senses its way by finger-like small protrusions called filopodia. In order to form these protrusion and to move the cell utilizes an active interplay between the plasma membrane and the cytoskeleton, and a realm of interacting proteins and $\mathrm{Ca}^{2+}$ signaling.

Cell migration can be divided into mesenchymal, amoeboid and multicellular migration. Mesenchymal cell migration is dependent on protrusions, integrin-mediated adhesions and retraction cycles. This is a form of cell migration observed in for instance fibroblasts. The cells are often highly polarized with a distinct lamellipodia, forming the leading edge. The adhesions are involved in pulling the cell forward [60]. Amoeboid migration is used by fast moving cells, like leukocytes and is characterized by frequent membrane extensions called pseudopodia [61]. In a $3 \mathrm{D}$ setting the amoeboid migration is distinguished by blebbing and squeezing through the extracellular matrix (ECM) while mesenchymal migration is characterized by multiple pseudopods (protrusion) and matrix degradation e.g. by matrix metalloproteases (MMPs) [62]. The cells can transition between these two modes of migration in $3 \mathrm{D}$ matrices [63, 64]. Multicellular migration is not completely separated from single cell migration. It occurs during wound healing and in the renewal process of for example the intestinal epithelia $[65,66]$.

\section{Actin and its partners}

The cytoskeletal protein actin is the main component of the motility machinery of the cell. Actin exists in two forms: monomeric (G-actin) and filamentous (F-actin), where F-actin polymerizes at the fast-growing, barbed end and depolymerize in the other, pointed end. Monomeric actin has the ability to bind ATP and upon ATP-binding the G-actin monomers spontaneously polymerize, making it a very costly event energy-wise for the cell.

The actin dynamics is a complex interplay of numerous proteins. Actin-binding proteins (ABPs) interact with the actin molecules of the ABPs are in turn regulated e.g. the Rho family's small GTPases. Elongation or nucleation of actin is mediated by several different proteins. One well studied ABP is the actin-related protein (Arp) 2/3 that branches the actin with the help of among others the Wiskott-Aldrich syndrome protein (WASP) [67, 68]. The formin proteins nucleate the actin at the barbed end at the same time as they prevent the end from being capped [69]; the 
capping protein prevents further elongation of the actin filaments [70]. Myosin II binds to the actin filaments where it functions as a contractile force on the cytoskeleton. Through phosphorylation it regulates tension in the actin cytoskeleton [71].

The GTPases control binding of the ABPs and hydrolyse GTP and thereby act as molecular switches between active (GTP-bound) and inactive (GDP-bound) state [72, 73]. The most extensively studied GTPases are Rac, Cdc42 and Rho. Formation and extension of the lamellipodia is closely regulated by these three GTPases. For an extensive review regarding GTPases and protrusion formation see [74].

\section{Aquaporins in cell migration}

As mentioned earlier several groups have shown the importance of AQPs in cell migration [13, 18, 30, 48, 58, 75]. Karlsson et al. [31, 40, 76], have, for instance, shown how AQP9 is involved in the formation of cellular protrusion and blebs, as well as in the process of cell migration. From the results a hypothetical mechanistic model was developed, where AQP9 is proposed to accumulate in the plasma membrane with a subsequent water influx creating a pressure-induced space between the actin cytoskeleton and the plasma membrane. Thus allowing the actin polymerization with all its protein machinery to take place, rendering formation of cellular protrusions such as filopodia $[48,49,58]$. AQP9 has also been proposed to be involved in both single cell and multicellular migration. Single cells transfected with AQP9 are morphologically active and highly motile [40,76]. When AQP9-expressing cells are allowed to form cellular monolayers they facilitate rapid wound closure [17].

AQP1 has been shown to be involved in endothelial cell migration in angiogenesis [77] and a similar model as for AQP9 has been presented for both AQP1 and AQP4 [78]. AQP1 has also been observed to interact with the cell adhesion associated protein Lin7. Reduced AQP1 expression reduce $\operatorname{Lin} 7 / \beta$-catenin interactions, affecting the formation of focal adhesions [79]. Regarding the role of AQPs in multicellular migration, it has been shown that AQP3-deficient mice exhibit impaired wound healing in both skin and cornea [80, 81], as well as reduced colonic epithelial renewal [82], i.e. in all instance where multicellular cell migration play a significant role.

\section{Macrophages and the innate immune system}

The immune system is broadly divided into the innate and the adaptive immune system. The focus for this thesis is on the innate immune system, our first line of defence. For an overview and a deeper description of the adaptive immunity see [83-87]. The innate immune response involves cells and molecules in our outer barriers like skin and mucosal epithelia, macrophages and dendritic cells (DC) that are tissue residual cells, as well as cells like polymorphonuclear neutrophils (PMNs) and monocytes circulating the blood. The complement system also counts to the innate immune system but has important roles in the adaptive one as well [88]. The innate immune response relies on the secretion of different defence- and pathogen-destroying agents and molecules, clearance of pathogens by phagocytosis and serves as a link to the cells of the adaptive immune system. As the first line of defence the role for innate immune system is to react to signals from attaching and/or invading pathogens. These signals are called pathogen- 
associated molecular patterns (PAMPs), which are conserved structured shared by many pathogens, and damage/danger-associated molecular patterns (DAMPs). These signals are largely recognised by receptors collectively called pathogen recognition receptors (PRRs).

The phagocytic macrophages were first discovered by Ilya Metchnikoff in 1884 [89, 90]. They differentiates from hematopoietic stem cell (HSCs) and are present in most tissues. They were long believed to all differentiate from monocytes originating from HSCs but recent research suggests that tissue resident macrophages are evolved from cells in the yolk sac, present before the appearance of HSCs in the embryo [91]. However, it seems that tissue resident macrophages can be of both yolk sac and HSCs lineages [92] and that they are cooperating in the induction of inflammation [91]. Macrophages are present in almost all tissues in different shapes and forms with specialized functions. In the liver as Kupffer cells, in the brain as microglia, in the skin as Langerhans cells and as osteoclast within the bone [93]. During an infection monocytes are recruited to the site with bacteria. They follow a well-established pattern of rolling, adhesion, crawling on the endothelial of the blood vessel in a complex interplay between selectins, integrins and vascular (VCAM) and intercellular (ICAM) cell adhesion molecules followed by migration through (transcellular) or between (paracellular) the endothelial cells. In the tissue the monocytes move through chemotaxis towards the site of infection meanwhile they mature into macrophages.

Macrophages can be both pro-inflammatory and anti-inflammatory and are roughly divided into M1 (classically activated) and M2 (alternatively activated) macrophages [94, 95]. M1 macrophages are activated by microbial products and pro-inflammatory cytokines, like TNF and Interferon $\gamma$ (IFN- $\gamma$ ), and have inflammatory and microbicidal properties. They produce reactive oxygen species (ROS) and the inducible nitric oxide synthase (iNOS) that catalyses the production of nitric oxide (NO) from the amino acid L-arginine. M2 macrophages are antiinflammatory and are induced by anti-inflammatory cytokines like IL-4, IL-10 and IL-13. They have more regulatory properties and are not microbicidal. They express arginase that inhibit NO production and instead produce ornithine from L-arginine which is a precursor of polyamines [96]. M2 macrophages have shown to have implications on wound-healing [95].

When encountered with a microbe the PMNs and the macrophages are able to elicit a NAPDHoxidase-mediated respiratory burst, which includes the production and release of ROS, such as radical superoxide, hydroxyl radicals and hydrogen peroxide $\left(\mathrm{H}_{2} \mathrm{O}_{2}\right) \cdot \mathrm{H}_{2} \mathrm{O}_{2}$ is a relatively stable reactive oxygen species that diffuses over cell membranes, where it is maybe converted into highly reactive hydroxyl radicals that can cause oxidation of proteins, DNA damage and peroxidation of lipids [97]. A target for $\mathrm{H}_{2} \mathrm{O}_{2}$ is the mitochondria where it can disrupt the membrane potential and release cytochrome $\mathrm{c}$ into the cytosol, which in turn can lead to apoptosis through activations of caspases [98], thus the respiratory burst of ROS may also affect host cells and cause tissue damage.

To eliminate the invading bacteria or destroy virus-infected cells, the macrophages use phagocytosis. The macrophages use a wide range of receptors such as PRRs, complement receptors and Ig-antibody-binding receptors (FcRs) to bind e.g. the bacteria to the cell membrane. Through actin and membrane signaling, much similar to the ones involved in the formation of membrane protrusion and cell migration the bacteria are engulfed, creating the 
phagosome. The phagosome is fused with lysosomes in the process of maturation to a fully functional phagosome. Lysosomes are membrane vesicle with a low $\mathrm{pH}$ containing hydrolytic enzymes that will degrade and destroy the bacteria [99]. Both extracellular and intracellular bacteria have evolved ways to evade phagocytosis and/or the maturation of the phagosome to avoid destruction [100].

\section{Aquaporins in the immune system}

AQPs are expressed in human immune cells both in the innate and the adaptive immune system. AQP1, 3 and 5 are for instance expressed in B- and T-lymphocytes and AQP3 and 5 in dendritic cells [101] while AQP9 is the primary AQP in human leukocytes [102].

AQP7 has been shown to be involved in the process of chemokine-dependent migration and antigen uptake and processing in DCs. AQP7 deficient mice DCs show lower cellular uptake of both low- and high-molecular-mass substances and reduced chemokine-dependent migration [103]. During T-cell migration in a chemokine gradient, the cells are assumed to utilize uptake of $\mathrm{H}_{2} \mathrm{O}_{2}$ through AQP3. The expression of AQP3 and the intake of $\mathrm{H}_{2} \mathrm{O}_{2}$ are needed for activation of $\mathrm{Cdc} 42$ and without $\mathrm{AQP} 3$ there is a defective $\mathrm{F}$-actin dynamics reducing migration capability [104]. $\mathrm{H}_{2} \mathrm{O}_{2}$ has besides its microbicidal and apoptosis-inducing characteristics been shown to work as a chemoattractant $[57,105]$. Epithelial cells in damaged tissue activate the NAPDH oxidase and produce $\mathrm{H}_{2} \mathrm{O}_{2}$ that recruits leukocytes. AQP1 [106], 3 [107, 108], 8 [106] and 9 [109] are all permeable to $\mathrm{H}_{2} \mathrm{O}_{2}$. Neutrophils and macrophages have the ability to reduce $\mathrm{H}_{2} \mathrm{O}_{2}$ in tissue through their myeloperoxidase that consumes $\mathrm{H}_{2} \mathrm{O}_{2}$ in its catalytic reaction [110]. AQP3 knockout mice show impaired $\mathrm{NF \kappa B}$ activation of keratinocytes and increased intracellular $\mathrm{H}_{2} \mathrm{O}_{2}$ in connection to the chronic inflammatory disease psoriasis [107]. It is possible that the expression of AQPs and their permeability to $\mathrm{H}_{2} \mathrm{O}_{2}$ both influence chemotaxis abilities, migration in itself as well as clearance and control of extracellular and intracellular $\mathrm{H}_{2} \mathrm{O}_{2}$ by cells.

\section{Bacteria}

The Latin word "bacteria" originates from the Greek bakterion "small staff" and is the diminutive of bactron that means stick or rod. Bacteria are prokaryotic organisms lacking membrane bound organelles like nucleus, Golgi apparatus and endoplasmic reticulum. Their size range from 1-20 $\mu \mathrm{m}$ (comparing roughly to the human cells that range from 10-100 $\mu \mathrm{m}$ ) and are represented in rod, spheres or spiral shapes. Bacteria were likely one of the first life forms on earth and represent a very diverse group that can be found all over the world in all kinds of environments with various characteristics.

Pseudomonas aeruginosa is a Gram-negative opportunistic bacterium that can infect numerous host species, including invertebrates, higher plants, mushrooms and vertebrates. In humans, the bacteria cause both acute and chronic infections, e.g. in the pulmonary and urinary tract as well as wound infections, especially in immune-compromised individuals. P. aeruginosa is in the top five of the microorganisms causing these types of infections in the ward [111]. Pseudomonas means false unit from the Greek words "pseudo" meaning false or untrue and "mono" meaning single unit, respectively. Aeruginosa is the Latin word for verdigris/copper 
rust. $P$. aeruginosa is a rod-shaped bacterium that is motile thanks to the presence of a polar flagella and type 4 pili. Both are of great importance for the adhesion of the bacteria to host epithelial cell especially in acute infections [112]. It can form biofilms, which give the bacteria the advantage to work as one unit on a population level and act as protection against environmental changes and for instance the human immune system. The bacteria have a distinct, sweet smell that reminds of toffee or as a summer meadow. In a P. aeruginosa wound infection e.g. in chronic leg ulcers there is a characteristic greenish and metallic coloration of the bacterial biofilms and also such a characteristic smell. The molecule causing the odour has been identified as 2-aminoacetophenone [113]. The characteristic greenish/bluish colour of $P$. aeruginosa comes from its production of the water-soluble molecules pyocyanin and pyoverdin. The bacteria can be found in a variety of environments including but not limited to water, soil, skin and lung.

$P$. aeruginosa has few nutritional requirements which makes it difficult to eradicate. The bacteria often only need acetate and ammonia as carbon and nitrogen sources and can grow anaerobically as well as aerobically. It does not ferment but rather obtains its energy from oxidation of sugars.

\section{Virulence factors}

Virulence is most often used to characterize the capacity of a microbe to cause disease. Virulence comes from the Latin word virulentus what means "full of poison" [114]. The virulence factors help the bacteria to invade its host, cause disease and evade host defence.

P. aeruginosa expresses several virulence factors, such as lipopolysaccharide (LPS), flagella and pili. Pseudomonas also produces different toxins. Some of the toxins are secreted but some are injected into host cells via the Type III secretion system of the bacteria. Exotoxin A is one of the most prominent toxins of $P$. aeruginosa [111]. Exotoxin $U$ is a phospholipase and cause death in host cells via necrosis while Exotoxin S disturbs the host via both C-terminal ADPribosyltransferase (ADPRT) and N-terminally with GTPase-activity [115]. This interferes with the actin cytoskeleton of the cells and block phagocytosis [116]. But the bacteria also produce lectins, elastases, proteases, phospholipase $\mathrm{C}$ and pyocyanin that all contribute to the virulence of Pseudomonas. Proteases degrade immunoglobulins and disrupt tight-junctions between epithelial cells. Elastases also disrupt tight junctions and cleaves surfactant proteins A and D in the respiratory tract which decrease the immune response [117]. Phospholipase $\mathrm{C}$ also destroys the epithelium by disrupting the glycocalix that is protecting the respiratory tract. Pyocyanin interferes with the redox cycling and the electron transport chain of the host cells and is thought to protect the bacteria from reactive oxygen and nitrogen species (ROS and NOS) produced by the immune cells [115]. During acute infections the bacteria utilizes many of its virulence factors but in chronic infections it is known to lose some of its virulence factors, like the flagella and pili [118]; this is probably due to an attempt to avoid the immune system. Transcription of most virulence factors and toxins are governed by the QS system $[115,117,119,120]$ and in the process of biofilm formation many of the virulence factors are crucial for P. aeruginosa.

The envelope of Gram-negative bacteria consists of two membranes, an outer membrane and a cytoplasmic. The outer membrane in most Gram-negative bacteria is mainly comprised of LPS 
(Fig. 1 A), previously also referred to as endotoxin. LPS can cover up to $75 \%$ of the surface [121], and its lipid A compound is seen as an endotoxin. The bacteria release small amounts of LPS as part of their normal metabolism and life cycle in outer membrane vesicles (OMV). The OMVs contains different bacterial substances and are used by bacteria as tools of long distance communication, to deliver virulence factors [122] and modulate immune responses [123].

The human immune system reacts strongly to LPS and this can lead to severe sepsis and death [124]. It binds to LPS-binding protein (LBP) and the Toll-like-receptor (TLR) 4, which leads to the activation of the transcription factor NFKB through the MyD88 and interleukin-receptorassociated kinase (IRAK) signalling pathways [125]. NFKB acts as a spider in the web of inflammatory responses. Activation of NFKB leads for instance to transcription of proinflammatory cytokines like tumour-necrosis factor (TNF) and interleukin $1 \beta$ (IL-1 $\beta$ ) [126] and IL-6 [127].

\section{Lipopolysaccharide and aquaporins}

Shefali Talwar et al., have shown [128] that AQP9 is upregulated in blood leukocytes after intravenous LPS stimulation in humans. When an infection gets into the blood stream (sepsis) a rapid and strong immune response is initiated and the patient can develop systemic inflammatory response syndrome (SIRS). In patients with SIRS, the expression of AQP9 is increased in blood cells [129], and in infective endocarditis patients the level of AQP9 is also elevated [130]. Through studies in our lab where blood derived macrophages and human primary neutrophils were stimulated with LPS we could observe an increased transcription and expression of AQP9 (Fig. 2ABC). Others have also shown an increase in the AQP1 expression in human leukocytes following LPS stimulation [131].

Sepsis has detrimental effects on the whole body and affect numerous organs. Systemic LPS stimulation in rats leads to elevated levels of AQP9 in the brain [132] and LPS-induced TNF secretion can cause the down-regulation of AQP8 in rat liver [133]. AQP1 expression in the kidney could have a protective role in LPS induced endotoxemia (presence of LPS in the blood stream). Knock-out mice lacking AQP1 show a predisposition to endotoxemia-induced acute kidney injury [134]. Taken together, these data are adding pieces to the puzzle of emerging data for a role of AQPs and especially AQP9 in the immune response to bacterial infections. 
A.

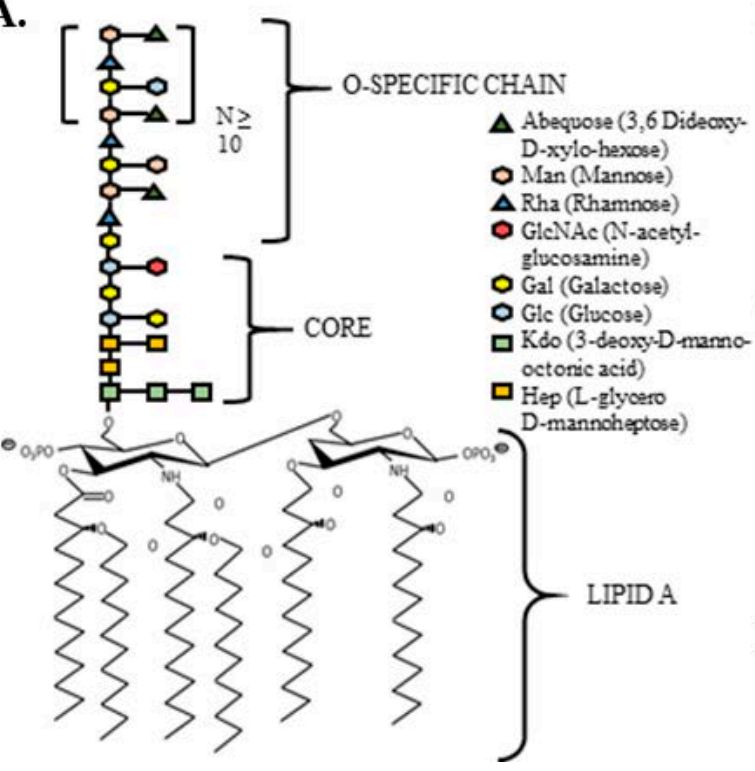

B.

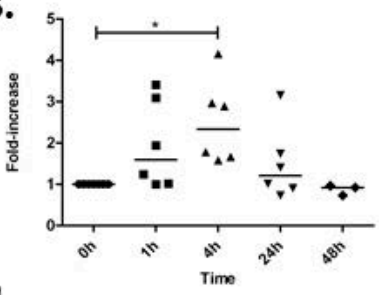

C.

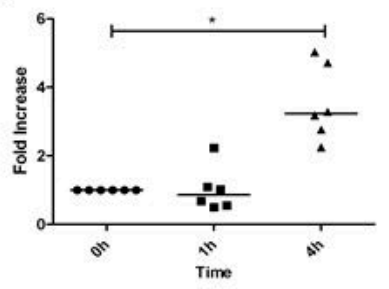

D.

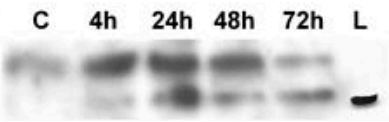

Figure 2. AQP9 expression in LPS-treated human primary leukocytes A. General structure of Salmonella typhimurium LPS. D. AQP9 mRNA expression in Salmonella typhimurium LPS-stimulated human primary macrophages. B. AQP9 mRNA expression in LPS-stimulated neutrophils. C. AQP9 protein expression in LPStreated primary macrophages. $\mathrm{n}=6$. Statistical analysis was performed using Wilcoxon signed rank-test, $p$-value $<0.05(*)$ was considered significant. Unpublished data.

\section{Quorum sensing}

P. aeruginosa, as many other bacteria, uses the small molecule-based communication system of quorum sensing (QS) [135]. This is dependent on population density and at low population density the QS-molecules are produced at low concentrations and will diffuse away without further effects. The bacteria will stay in a non-virulent, slow-growing state. When the population density has reached a certain threshold (quorum) the concentrations of QS molecules can change the transcriptional behaviour of the bacteria and the size of the bacteria population as a whole [136-138]. The QS thus enables the bacteria population to live as a community, almost as a multicellular organism.

P. aeruginosa has three different subordinated QS systems. Two are of the so-called LuxI/LuxR-type and the third is called Pseudomonas quinolone signal (PQS) system. The LuxI/LuxR-types are $N$-acylhomoserine lactone (AHL)-dependent. The AHLs work as auto inducers (AIs). They can positively enhance the production of themselves, leading to an escalating signaling process that is called auto induction. The first LuxI/LuxR-type system, LasI, produces the $N$-3-oxo-dodecanoyl- $L$-homoserine lactone $\left(3 \mathrm{O}-\mathrm{C}_{12}-\mathrm{HSL}\right.$ ) by LasI AHLacyl-synthase. The $3 \mathrm{O}-\mathrm{C}_{12}$-HSL binds to its receptor LasR which associate with gene promotors containing las boxes in a dimerized form, turning on several genes among e.g. elastase and the lasI (coding for the LasI synthase) gene itself. The second AHL system, named RhlI are 
subordinated by the LasI and produces $N$-butyryl- $L$-homoserine lactone $\left(\mathrm{C}_{4}-\mathrm{HSL}\right)$ that recognizes the receptor, RhlIR. The $\mathrm{C}_{4}$-HSL-RhlIR complex initiate transcription of, for example, ramnolipids that are biosurfactants used by the bacteria for late stage of biofilm formation. Ramnolipids cause necrosis in leukocytes [139].

The PQS system consists of alkyl-quinolones, specifically 2-heptyl-3-hydroxy-4-quinolone. The PQS is synthesized pqsABCDEF genes products and are recognised by the Pqs-receptor. All system are connected within a hierarchy where the Las system becomes active first and stimulates both Rhl and the PQS system. LasI can also inactivate the Rhl system by dissociating the RhlR dimer. Thus, PQS activates Rhl while Rhl inhibits PQS.

\section{Quorum sensing and the host}

The QS system is a potential target in the development of new ways to tackle infections without using antibiotics [140]. Targeting the bacterial virulence could affect the pathogenicity of the bacteria but would likely not drive resistance development as hard as traditional antibiotics since it is not killing the bacteria or affecting the bacterial growth directly. Through its diverse ways to alter the immune system it has also become a potential target for the development of drugs for treating inflammatory diseases like rheumatoid arthritis (RA) [141-143]. By altering the QS-molecules so that they keep their ability to interact and affect the immune system but removing its bacterial QS functions these compounds could provide us with new medicines to treat inflammatory and autoimmune diseases.

QS does not only affect the bacteria and its neighbouring microbes but it has been shown to affect and influence the behaviour of human host cells. Thus, it is of importance to study these interactions to eliminate adverse effects of any QS-modulating drug.

P. aeruginosa $3 \mathrm{O}-\mathrm{C}_{12}$-HSL has been shown to be a strong chemoattractant [4, 144], alter cell migration [145] and enhances the phagocytosis of yeast in human macrophages [146]. It has also been seen to affect the integrity of epithelial cell layer through disruption of the junction complexes, and displayed the capacity to modulate calcium signaling via modulation of calcium stores and influxes [147, 148]. For a long time there was no specific receptor identified for AHLs in mammalian cells. The bitter taste receptor T2R38 were found to work as a sensor for $3 \mathrm{O}-\mathrm{C}_{12}$-HSL and biofilms in phagocytes $[149,150]$ and proposed as the receptor for $3 \mathrm{O}-\mathrm{C}_{12}$ HSL. There is several targets identified for AHLs. They trigger a diverse set of signaling pathways including MAPK, activation of Rho GTPases that are important in cell migration and the transcription factor $\mathrm{NF} \kappa \mathrm{B}$ that plays a central role in the expression of pro-inflammatory mediators $[4,151,152]$. 3O-C 12 -HSL may interact directly with phospholipids in membranes [153] and when entering the host cell [154], and use the peroxisome proliferator-activated receptor (PPAR) to interfere with $\mathrm{NF \kappa B}$ signaling $[155,156]$. The IQ-motif-containing GTPase-activating protein IQGAP1 was identified as an allegeable target for $3 \mathrm{O}-\mathrm{C}_{12}$-HSL [145]. IQGAP has multiple domains for binding other proteins and interact directly with the Rho-GTPases, Rac1 and Cdc42 that are involved in cell shape and directed migration [157$160]$. By interacting with actin, myosin, MAPK and E-cadherin [159, 161], IQGAP can be seen as a true scaffolding protein in the cytoplasm regarding cytoskeleton modulation. 


\section{Virus}

Viruses are defined as ultramicroscopic (20-300 nm) infectious agents that are only capable to replicate in a living host cells. The word "virus" is Latin meaning poison or slimy/noxious liquid [162]. Viruses are built-up by RNA or DNA, enclosed within a protein coat. Some have an additional membrane envelope. They cause a wide range of diseases in man ranging from the common cold like Corona- and Rhino-viruses [163] to severe infections like influenza, and EBOLA.

The Crimean-Congo haemorrhagic fever virus (CCHFV) belongs to the Nairovirus genus in the Bunyaviridae family. It is an arthropod-borne virus that is transmitted by tics of the genus Hyalomma; it is highly pathogenic and causes severe haemorrhagic fever [164]. The virus is widely spread in Africa, the Middle East, Asia, and in south-eastern Europe [165]. The symptoms include high fever, myalgia, headache, nausea, vomiting, abdominal pain, petechiae and haematomas and in the acute phase extensive haemorrhages [164-166].

The virus is enveloped and has a three-segmented negative-sense genome including; the $\mathrm{S}$ (small)-segment that transcribe the nucleocapsid protein (NP), the M (medium)-segment that encodes two surface glycoproteins and the L (large) segment that encodes the RNA-dependent RNA polymerase [167]. The virus enters and overcomes the epithelial barrier via the tick bite and enters the vascular system. The virus get inside the epithelial cells via clathrin- and cholesterol-dependent endocytosis [168], replicates in the cytoplasm and are newly formed virus are released from the cell side facing blood vessels [169]. The microtubules, a critical part of the cell cytoskeleton and migration machinery, are involved in the entering, replication and assembly of the virus in the cytoplasm, as well as in the viral exit of the host cell [170].

The immune system usually responds quickly to a viral infection with the production of the type I interferons (IFNs). IFNs work as antiviral molecules, immune modulators and antiproliferative molecules [171], and through the Jak/Stat signaling pathway they regulate gene expression [172] and recruit innate immune cells to the site of infection and have immune modulatory effects on the adaptive immune system. In the innate system the IFNs have three direct effects by i) transcription of RNases that can break down viral RNA, ii) arresting the protein synthesis machinery which prevents the assembly of new virus and iii) inducing apoptosis in the infected cell $[172,173]$. However, by replicating in non-antigen-presenting cells, fibroblasts and endothelial cells that can transfer the virus to the systemic circulation of the host, the virus may manage to overcome the immune system. In the acute phase of the disease damage to the endothelium, vascular leakage and subsequent haemorrhages appear as a direct result of virus infection or an immune response-mediated indirect effect or both [174, 175]. In patients with severe $\mathrm{CCHV}$ infections there are increased levels of cytokines such as TNF- $\alpha$, IL-6 and IL-8, as well as other inflammatory markers like the transcription factor VEGF-A and the adhesion molecules ICAM-1 and VCAM-1 [176, 177]. But so far the knowledge of CCHFV-host interactions are limited.

To work with CCHV a facility with the highest biosafety level, BSL-4 is required. This aggravates the research of specific anti-viral therapies as well as deeper knowledge about the host-virus interactions on a molecular level $[178,179]$. The Hazara virus is closely related to 
CCHFV. It also belongs to Nairovirus genus and Bunyaviridae family. For example, Hazara shows high homology in the nucleocapsid protein (around 80\%). But the Hazara virus are nonpathogenic to humans[165]. This makes it suitable as an experimental model for CCHFV [166, $180]$.

\section{Viruses and aquaporins}

Keeping an intact barrier function and permeability of the vascular system is crucial for normal function and homeostasis, which is however controlled by many modulators [181]. AQPs are involved in regulating cellular and tissue water homeostasis and thereby fluid secretion from glands, cell volume, organelle physiology, and cell migration [17, 75, 182-184]. A few studies have highlighted AQPs as being important in viral infections. Thus, cirrhotic liver tissue in a chronic Hepatitis B virus infection shows an increased AQP1 expression [185]. In pulmonary adenoviral infections both AQP1 and AQP5 were down-regulated in mouse lung epithelia cells [186] and in the acute phase of Herpes simplex virus infections AQP4 is decreased followed by an upregulation together with AQP1 in the long term disease [187]. Yang et al., showed how expression of the rotavirus toxin NSP4 induces cell morphology changes, protrusion formation and how the toxin is spread through cell-cell contacts[188]. And even though that study did not look at the expression or modulation of any specific AQP, they are likely to be involved based on the increasing data indicating their role in membrane protrusion formation and cell volume regulation.

It is clear that in the struggle to survive both microbes and humans use a wide range of different tactics and both sides have learned from the other and evolved in close connection. The hostpathogen interactions is a dynamic, ever evolving process. Interestingly, increasing data as presented above strengthen the relatively new notion of AQPs as important players in these host-pathogen interactions.

\section{Water homeostasis in the intestine}

Normal water homeostasis in the intestines relies on osmotic gradients, ion channels and AQPs. The water that passes through the gut is partly derived from the diet (approx. 2L/day) and partly from digestive juices (approx. 7L/day) that is secreted in the mouth and stomach. Most fluids are absorbed again together with nutrients in the small intestine, but it is in the colon where most water absorption and solidification of the faeces takes place [189]. In the small intestine the secretion and uptake relies on isotonic mechanisms while in the colon the water uptake goes against an osmotic gradient. The intestinal epithelium is a crucial part our immune defence and serves as a barrier for our normal flora and harmful microbes. The barrier function relies strongly on the intercellular adhesions composed of tight adherence-junctions and intercellular signalling via gap-junctions. At the same time the intestines must be permeable enough to absorb nutrients and water, and to secrete digestive juices.

A dysregulation in the water-homeostasis caused by infections or inflammation in the intestine can lead to diarrhoea. The clinical definition of diarrhoea is the passage of three or more loose or liquid stools per day. The most commonly used diagnostic tool for stool consistency and appearance is the "Bristol scale stool and form" that was introduced by Heaton and Thompson 
[190]. According to these criteria, diarrhoea, together with passage frequency, correspond to scale 6 and 7. Infections of gastrointestinal tract by pathogenic bacteria like Salmonella, E. coli, and Cholera as well as viruses like Rotavirus and Calici-virus, are common causes of diarrhoea. Diarrhoea can also be a symptom on chronic inflammatory diseases and in some instances colonic polyps and colon cancer.

\section{Aquaporins in gastrointestinal homeostasis and diarrhoea}

AQPs play a pivotal role for normal gastrointestinal homeostasis, all from the secretion of saliva where AQP5 plays an important role [191-193], through the water-tight regulated stomach where AQP1, 3 and 4 play major roles in the secretion of gastric juices [189, 194-196] and the small intestine, where enterocytes immense bidirectional water transport where AQP1, 3, 7, 10 and 11 are expressed $[189,195,197]$ to the ascending colon where primarily AQP1, 3, 7, 8 and 11 are present [198-200]. Several studies have displayed the importance of AQPs in faecal concentration/water absorption in the colon. In a study on rats the inhibition of the AQP3 was shown to cause watery diarrhoea [201] and during exposure to mercury, the common inhibitor of AQPs, both AQP3 and 4 as well as 7 were downregulated and therefore believed to be involved in the mechanism of mercury-induced toxicity and gastrointestinal symptoms [202]. Wang et al also showed that AQP4 knockout mice demonstrated a higher water content in faeces [203]. Also pathogen-induced diarrhoea influences the expression of AQPs, and Guttman et al., showed for instance how the attaching and effacing (A/E) bacteria Citrobacter rodentium caused re-localisation of AQP2 and 3 in mice [204]. A dysregulation of AQPs is likely to affect the process of normal intestine homeostasis and to be involved in the mechanism and induction of diarrhoea.

\section{Inflammatory bowel disease and microscopic colitis}

Chronic inflammatory diarrhoeal diseases (IBDs, inflammatory bowel disease; IBS; inflammatory bowel syndrome; MC, microscopic colitis; CC, collagenous colitis; LC, lymphocytic colitis) are all diseases with diarrhoea as a predominant symptom. In the Western society the prevalence of inflammatory bowel disease is approaching $1 \%$ and in Sweden the percentage is around $0.65 \%$. [205]. IBD is divided into ulcerative colitis (UC), Crohn's disease (CD), microscopic colitis (MC) and indeterminate colitis.

In patients with chronic diarrhoea, 10-20\% are diagnosed with microscopic colitis (MC) [206] and the number of patients even exceed those with Crohn's [207]. Clinical symptoms are frequent, non-bloody diarrhoea, weight loss and abdominal pain. The watery consistency of the diarrhoea in MC corresponds to Bristol stool scale 7 and leads to urgent faecal incontinence in a majority of the patients with a severe impact on their quality of life (QOL) [208].

MC was introduced as an umbrella term for collagenous colitis (CC) and lymphocytic colitis (LC) by Read in 1980 [209]. To characterize MC and distinguish the two subgroups requires histopathological examination of colonic biopsies [210]. LC is characterized by the infiltration of immune cells in the lamina propria, whereas CC is distinguished by a sub-epithelial collagenous layer. CC was first described by Lindström in 1976 [211]. The disease has a female predominance and the onset is commonly between $60-70$ years of age [212]. The only effective 
treatment for $\mathrm{MC}$ is the glucocorticoid budesonide [213]. Budesonide treatment induces clinical remission in around $80 \%$ of patients and improves stool consistency and passage frequency rapidly [214]. Since stool consistency has been shown to be the main determinant for impaired QOL [215], budesonide treatment has a great impact on the patient's everyday life. Risk factors for MC include age, use of nonsteriodal anti-inflammatory drugs (NSAIDs) or proton-pump inhibitors, antidepressants or antipsychotic drugs [216]. Smoking has also been shown to have negative effects on the treatment response and stool consistency [217]. Changes in the gut microbiota have also been reported in MC patients compared to healthy controls, albeit with few participants [218]. Moreover, in a study Bürgel et al., showed how the diarrhoeal mechanism in $\mathrm{CC}$ is influenced by reduced $\mathrm{Na}^{+}$- and $\mathrm{Cl}^{-}$-fluxes over the gut epithelium and that it is accompanied by a secretory component of active chloride secretion [219]. Still, patients with CC do not show any clear electrolyte imbalances, which otherwise is common in diarrhoeal diseases. Classical histological findings in CC do not correlate with symptoms [217, 220], and furthermore, it is not to be expected that histological changes occur as rapidly as clinical improvement (within days), which is seen following budesonide treatment. This raises the questions on what diarrhoeal mechanisms are driving the disease and how budesonide influences stool frequency and improves stool consistency.

\section{Aquaporins in inflammatory bowel diseases}

At early stages of Crohn's disease and ulcerative colitis AQP1, 3, 7 and 8 have been shown to be downregulated [221] and it was speculated that this decrease is involved in the development of the disease. Immunohistochemistry analysis shows a difference in the expression in different segments of the bowel. Hardin et al., could also see a downregulation of AQPs in a murine model for colitis as well as in UC, CD and infectious colitis patients [222]. Whereas Zahn et al showed an increase of AQP8 expression in UC patients compared to controls [223]. A different regulation of AQPs in UC and Crohn's disease compared to healthy controls speaks for a possible expressional dysregulation of AQPs in MC. Especially when considering the watery diarrhoea without electrolyte imbalance in MC patients, an involvement of AQPs is likely. 


\section{HYPOTHESIS}

We hypothesize that in response to infectious agents and inflammatory cues cells need to change their distribution and expression of AQPs in order to handle environmental changes and challenges including volume change, migration, and phagocytosis as well as to maintain cellular and organ water homeostasis during infections and inflammation.

\section{AIM}

The general aim for this thesis was to elucidate the potential role and expression of aquaporins in infection and inflammation.

More specifically the project aimed to:

\section{PAPER I}

Investigate the contribution of $P$. aeruginosa quorum sensing (QS) genes lasI/rhlI and effects of their products on phagocytosis, cell morphology, AQP9 expression, and distribution in human primary macrophages.

\section{PAPER II}

Assess in greater detail the bacteria-host cell communication between $P$. aeruginosa and human primary macrophages regarding the effects of the QS molecule $3 \mathrm{O}-\mathrm{C}_{12}-\mathrm{HSL}$ on cell morphology, area, and volume as well as AQP9 characteristics of the macrophages.

\section{PAPER III}

Study the effects of Crimean-Congo Haemorrhagic fever virus (CCHFV) and Hazara virus infections on AQP6 characteristics, along with the potential impact of AQP6 on virus infectivity.

\section{PAPER IV}

Elucidate the expression and potential role of AQPs in microscopic colitis by investigating colonic biopsies from microscopic colitis patients, before and during budesonide treatment. 


\section{MATERIALS AND METHODS}

The following section will in brief describe the techniques and protocols used in this thesis. For a more detailed description please see Paper I-IV.

\section{Ethical considerations}

The studies were conducted in accordance with the Declaration of Helsinki. For paper I and paper II human blood were collected and buffy coats were obtained by employees at the Blood Bank at Linköping University Hospital, Sweden. A written consent for research use of donated blood was obtained from all donors. Since blood donation is classified as negligible risk to the donors and since only anonymized samples were delivered to the researchers, the study did not require ethical approval according to paragraph 4 of the Swedish law (2003:460; http://www.lagboken.se/dokument/Lagar-och-forordningar/4060/Lag-2003 460-om-

etikprovning-av-forskning-som-avser-manniskor?id=64991 ) on Ethical Conduct in Human Research.

The study for paper IV was ethically approved by the Regional Ethical Review Board, Linköping (Dnr. 2015/31-31). Both patients and controls were informed before colonoscopy and gave written consent to donate tissue samples for research purposes were obtained prior to procedure.

\section{Cells and cell culture}

\section{Isolation and culture of human primary monocyte-derived macrophages}

Human primary monocytes were isolated from healthy blood donor buffy coats as described in detail in [184, 224]. Briefly the leukocyte concentrate was obtained using Lymphoprep gradient (Axis Shield PoC AS, Oslo, Norway). The mononuclear cells were collected from the gradient, washed repeatedly in cold PBS, pH 7.3 containing heparin $(0.1 \mu \mathrm{l} / \mathrm{ml}$, LEO Pharma Ballerup, Denmark) and then in cold Krebs-Ringer Glucose buffer (KRG), pH 7.3 (120 mM NaCl, 8.3 $\mathrm{mM} \mathrm{KH}_{2} \mathrm{PO}_{4}, 4.9 \mathrm{mM} \mathrm{KCl}, 1.2 \mathrm{mM} \mathrm{MgSO}_{4}, 10 \mathrm{mM}$ glucose) before suspended in Dulbecco's Modified Eagle Medium (DMEM) supplemented with $25 \mathrm{mM}$ HEPES, $100 \mathrm{U} / \mathrm{ml}$ penicillin and $100 \mu \mathrm{g} / \mathrm{ml}$ streptomycin (Life Technologies, Grand Island, NY). The cells were seeded in culture flasks and left to adhere for $1.5-2 \mathrm{~h}$ before unbound cells were washed away with $37^{\circ} \mathrm{C}$ warm complete $\mathrm{KRG}$ (as above with addition of $1 \mathrm{mM} \mathrm{CaCl}_{2}$ ). The adherent cells were left to differentiate to macrophages for 7-8 days in DMEM supplemented as above and with addition of $10 \%$ human serum (serum obtained and pooled from 5 donors collected from Linköping University Hospital) and $80 \mu \mathrm{M}$ L-glutamine (Life Technologies). The cells were considered to be differentiated macrophages, according to their morphology and phagocytic properties to engulf two different prey, wild-type $P$. aeruginosa PAO1 [184] or heat-killed yeast Saccharomyces cerevisiae [225] at a macrophage : prey ratio of 1:10. For experiments, mature macrophages were harvested with trypsin-EDTA (Life Technologies), washed, counted and seeded. Cells were left to adhere in DMEM as above for at least $2 \mathrm{~h}$ or overnight at $37^{\circ} \mathrm{C}$ in $5 \%$ $\mathrm{CO}_{2}$ before experiments. 


\section{GFP-AQP6 expressing C3H10T1/2 chimeric cells}

For transient expression of GFP-AQP6 mouse embryonal C3H10T1/2 fibroblasts (ATCC, Manassas, VA) were transfected using the Turbofect transfection reagent (Thermo Scientific). cDNA encoding AQP6 from human kidney were ligated with pEGFP-C1 and pRetroQAcGFP1-C1 (Clontech Laboratories, Mountain View, CA) expression vectors, that were checked and sequenced (Macrogen Europe Laboratories, Amsterdam, the Netherlands) before transfection. C3H10T1/2 fibroblasts (ATCC, Manassas, VA) were cultured in Dulbecco's modified Eagle's medium F12 (DMEM F12) supplemented with 10\% fetal bovine serum, 100 $\mu \mathrm{g} \mathrm{mL} \mathrm{m}^{-1}$ streptomycin and $100 \mathrm{U} \mathrm{mL}^{-1}$ penicillin (Life Technologies, Grand Island, NY) at $37^{\circ} \mathrm{C}$ in $5 \% \mathrm{CO}_{2}$. For the transfections the cells were cultured on MatTek (MatTek Corporation, Ashland, MA) dishes and transfected with either pEGFP-AQP6 or pEGFP-C1 as a control. The virus infections were performed $24 \mathrm{~h}$ post-transfection.

\section{Bacteria}

The two $P$. aeruginosa strains used were wild-type PAO1 and its double mutant PAO1 lasI-

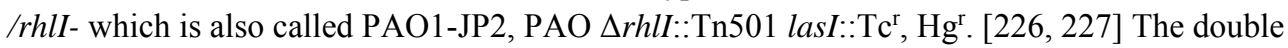
mutant is defective in the synthesis of QS molecules 3O-C $12-\mathrm{HSL}$ and $\mathrm{C}_{4}-\mathrm{HSL}$. Both strains constitutively express the stable green fluorescent protein, GFP, and were a kind gift from Prof. Thomas Bjarnsholt (University of Copenhagen, Denmark). Bacteria were grown in LuriaBertani (LB) liquid medium or on agar plates containing $150-200 \mu \mathrm{g} / \mathrm{ml}$ carbenicillin to maintain a stable expression of GFP; tetracycline (50 or $300 \mu \mathrm{g} / \mathrm{ml})$ and mercuric chloride (7.5 or $15 \mu \mathrm{g} / \mathrm{ml}$ ) were added (all from Sigma Aldrich, St. Louis, MO) to maintain the lasI-/rhlImutations.

\section{AHL synthesis}

$N$-3-oxo-dodecanoyl- $L$-homoserine lactone $\mathrm{C}_{16} \mathrm{H}_{27} \mathrm{NO}_{4}$, MW 297.4 (3O-C $\mathrm{C}_{12}$-HSL) and $\mathrm{N}$ butyryl- $L$-homoserinelactone were synthesized by Prof. Peter Konradsson and Lan Bui (Dept. of Organic Chemistry, Linköping University, Sweden) as previously described [142]. The molecules are structurally and functionally identical to those obtained from $P$. aeruginosa (Fig. $3 \mathrm{~B})$. The $3 \mathrm{O}-\mathrm{C}_{12}-\mathrm{HSL}$ was checked for identity and purity by HPLC, and its activity as a QSmolecule was confirmed by the bioassays described earlier [228, 229]. The AHLs were dissolved in $100 \%$ dimethylsulfoxide (DMSO) as a stock solution and then further diluted in PBS, pH 7.3 before added to the cells.

\section{Treatment with $\mathrm{AHL}$ and aquaporin inhibitors}

Macrophages were treated with $3 \mathrm{O}-\mathrm{C}_{12}$-HSL at 10,50 or $100 \mu \mathrm{M}$ for 1,4 or $24 \mathrm{~h}$ at $37^{\circ} \mathrm{C}$ in $5 \%$ $\mathrm{CO}_{2}$ and further proceeded for downstream imaging, qPCR and immunoblotting. As vehicle for $3 \mathrm{O}-\mathrm{C}_{12}$-HSL, $0.02 \%$ DMSO was used. To assess the role of AQPs, two kinds of water influx inhibitors were used: $\mathrm{HgCl}_{2}$, which blocks water transport activity of most AQPs through thiol binding to a pore-localized cysteine [37]; and HTS13286 a specific peptide inhibitor of AQP9 $[183,230,231]$. Macrophages were pretreated with 1 or $5 \mu \mathrm{M} \mathrm{HgCl}_{2}$ (Sigma Aldrich) or 25 $\mu \mathrm{M}$ HTS13286 (Maybridge, Cornwall, UK) for $20 \mathrm{~min}$ or was added to the cells simultaneously with $3 \mathrm{O}-\mathrm{C}_{12}$-HSL stimulation. As vehicle control for HTS13286, 0.25\% DMSO was used. 


\begin{tabular}{|c|c|}
\hline $\begin{array}{l}\text { Bacterial infection and } \\
\text { treatment with AHLs } \\
\text { Before infection, bacteria were } \\
\text { grown in LB medium overnight } \\
\text { at } 37^{\circ} \mathrm{C} \text { with shaking (Fig. } 3 \mathrm{~A} \text { ), } \\
\text { re-suspended in } 0.9 \% \mathrm{NaCl} \text { to } \\
\text { an optical density of } 0.09 \text { at } 600 \\
\mathrm{~nm}, \mathrm{OD}_{600}\left(1 \mathrm{x} 10^{8} \mathrm{CFU} / \mathrm{ml}\right) \text { and } \\
\text { further diluted in DMEM with } \\
25 \mathrm{mM} \text { HEPES without serum } \\
\text { and antibiotics. Macrophages, } \\
\text { on glass coverslips, were }\end{array}$ & $\begin{array}{l}\text { Figure 3. A. Pseudomonas aeruginosa in liquid culture showing } \\
\text { Pseudomonas aeruginosa PAO1 wildtype on the left and its double } \\
\text { mutant lasI-/rhlI- on the right displaying the lack of the } 3 \mathrm{O}-\mathrm{C}_{12}-\mathrm{HSL} \\
\text { controlled pyoverdin. B. Molecular structure of } 3 \mathrm{O}-\mathrm{C}_{12} \text { - HSL and } \mathrm{C}_{4}- \\
\text { HSL. }\end{array}$ \\
\hline
\end{tabular}
infected with bacteria at multiplicities of infection (MOI) 1,10 and 100 in fresh DMEM, incubated for $1 \mathrm{~h}$ at $37^{\circ} \mathrm{C}$ in 5 $\% \mathrm{CO}_{2}$ and further proceeded for the phagocytosis assay, imaging or immunoblotting. To examine a functional complementation of phagocytosis, macrophages were pretreated with a mixture of $25 \mu \mathrm{M} \mathrm{C}_{4}$-HSL and $50 \mu \mathrm{M} 3 \mathrm{O}-\mathrm{C}_{12}$-HSL (in $0.02 \% \mathrm{DMSO}$ ) for $4 \mathrm{~h}$ before infection at MOI 10.

\section{Virus}

Human adrenal cortex, adeno carcinoma SW-13 cells were used to produce a Hazara virus stock. The cells were maintained in Leibovitz's L15 medium (L15) supplemented with 10\% heat-inactivated fetal bovine serum, $25 \mathrm{mM}$ HEPES, $100 \mathrm{U} \mathrm{mL}^{-1}$ penicillin, $100 \mu \mathrm{g} \mathrm{mL}^{-1}$ streptomycin (Life Technologies) at $37^{\circ} \mathrm{C}$ in $5 \% \mathrm{CO}_{2}$.

\section{Virus infection}

Transfected C3H10T1/2 cells expressing pEGFP-AQP6, or pEGFP-C1 as a control, were infected with Hazara virus at MOI 1 and 100 for $1 \mathrm{~h}$ at $37^{\circ} \mathrm{C}$ in $5 \% \mathrm{CO}_{2}$ in serum free DMEM supplemented with $100 \mu \mathrm{g} \mathrm{mL}^{-1}$ streptomycin and $100 \mathrm{U} \mathrm{mL}^{-1}$ penicillin. After 1 -h infection, cells were rinsed and maintained for $24 \mathrm{~h}$ post infection at $37^{\circ} \mathrm{C}$ in $5 \% \mathrm{CO}_{2}$ before the supernatants were collected for further determination and quantification of virus, and cells were processed for imaging.

\section{Determination of virus by immunofluorescent assay}

The concentration of Hazara virus in the virus stock and in the cell supernatants obtained from infected GFP-AQP6 expressing cells were determined as described previously [232]. Briefly, $\mathrm{SW}-13$, or C3H10T1/2 cells in 96-well plates were infected with 10-fold serial dilutions of the virus stock or cell supernatants for $1 \mathrm{~h}$ at $37^{\circ} \mathrm{C}$ in $5 \% \mathrm{CO}_{2}$. Cells were fixed, permeabilized, labelled with rabbit anti-CCHFV/Hazara NP antibodies [232] and Alexa Fluor 488-conjugated goat anti-rabbit antibodies (Life Technologies). Fluorescent foci were counted in an Axiovert 35 fluorescence microscope (Carl Zeiss, Jena, Germany). The infectious virus titres were determined as in focus forming units per $\mathrm{ml}(\mathrm{FFU} / \mathrm{ml})$. 


\section{Visualization}

The word microscope comes from the Greek mikros (small) and skopein (to see). The principle of microscopy is based on the optical phenomenon that light converge when passing through lenses. Placing an object closer to the lens than the focal point the image generated on the other side of the lens is larger than the object. Focusing light with the help of a condenser on a sample will affect the light that passes through the sample, and passing through a series of lenses a magnification of the sample will be rendered [233].

Fluorescence microscopy is based on principle of Stokes' shift which means that a substance will always emit light at longer wavelength with less energy than that of the excitation light [234]. The resolution of a microscopic image is determined by point spread function (PSF). The PSF is the spreading of light from one single point. Passing through at the points of a specimen the light will be distorted, creating an interference pattern. For a single point this is illustrated by a so called Airy disc [233]. The ability to distinguish between two Airy discs is empirically defined as resolution. The resolution or the minimum distance to distinguish two points is defined by the Rayleigh criterion which is based on teh wavelength of the light used and the numerical aperture (NA) of the objective.

\section{Live cell imaging \\ 2D imaging}

To examine cell morphology and area changes, time-lapse videos of the cells were recorded using the JULI light, bench top microscope (NanoEnTek Inc., Seol, Korea) inside the incubator at $37^{\circ} \mathrm{C}$ in $5 \% \mathrm{CO}_{2}$. The image acquisition was performed at an interval of $1 \mathrm{~min}$ for $3 \mathrm{~h}$.

\section{D holographic imaging}

To analyse optical cell volume changes, time-lapse videos were recorded using the HoloMonitor M4 (Phase Holographic Imaging PHI AB, Lund, Sweden) inside the incubator at $37^{\circ} \mathrm{C}$ in $5 \% \mathrm{CO}_{2}$. Image acquisition was set at an interval of $30 \mathrm{~s}$ for $1 \mathrm{~h}$.

The M4 is based on digital holographic microscopy and is basically a quantitative phase contrast microscope. The technique allows a light wave passing through the sample, like a cell that is then compared to a reference light wave that does not pass through the sample. Combining these two waves creates an interference pattern. Phase shift images are constructed by computer-based processing of the digital holograms into topographic phase shift images. The phase shift is determined by the thickness and refraction index of the object. The image then contains both intensity and phase information making it possible to quantify numerous cell properties like cell area, volume and thickness.

\section{Epifluorescence imaging of living cells with spinning disc confocal microscopy}

After virus infection, transfected cells were placed in calcium-containing Krebs-Ringer Glucose buffer (120 mM NaCl, $4.9 \mathrm{mM} \mathrm{KCl}, 1.2 \mathrm{mM} \mathrm{MgSO}_{4}, 8.3 \mathrm{mM} \mathrm{KH}_{2} \mathrm{PO}_{4}, 10 \mathrm{mM}$ glucose, $1 \mathrm{mM}$ $\mathrm{CaCl}_{2}$ ). For high-resolution epifluorescent imaging, the probes were visualised and examined with Axiovert $200 \mathrm{M}$ (Carl Zeiss) microscope equipped with a structured illumination-aperture correlation unit (VivaTome, Carl Zeiss), an AxioCam MR CCD camera (Carl Zeiss), HXP 
120C fluorescent lamp, an objective heat-controller (Peacon, Erbach-Bach, Germany), and a 63x (NA 1.25; Carl Zeiss) objective.

In structured illumination aperture correlation microscopy the samples are illuminated through a spinning raster which enables mathematical extraction of a confocal image. The light passes through the excitation filter, and then the beam passes a spinning disc raster that only let $50 \%$ of the light pass through. The emitted fluorescence light from the sample will pass back through the disc to the detector. All $100 \%$ of the in-focus light and $50 \%$ of the out-of-focus light will pass through the slits in the grating and reaches the detector. The remaining $50 \%$ of out-offocus light will be reflected, but also this part of the emission is saved for subsequent image processing. Two signal components are thus acquired, representing the light that passed through (IFL) and the part was reflected by the spinning disc (OFL), respectively. By subtracting the out of focus light (OFL) image from the IFL a confocal image is rendered and adding the two together will yield a wide-field fluorescent image.

\section{Confocal and super resolution imaging \\ Laser scanning confocal microscopy (LSCM)}

Samples were washed with complete KRG, fixed with 4\% paraformaldehyde (Sigma Aldrich) for $20 \mathrm{~min}$, blocked in 1\% BSA and stained with rabbit anti-AQP9 antibodies (\#ab84828-100, Abcam, UK). For classical laser scanning confocal microscopy (LSCM), the specimens were further labelled with Alexa Fluor 568-conjugated goat anti-rabbit antibodies (Life Technologies). Finally, coverslips were mounted on glass microscope slides in ProLong Gold antifade reagent (Molecular Probes, Invitrogen). For LSCM, the specimens were examined through a $63 \times$ oil immersion objective with NA 1.40 in a Zeiss Axio Observer Z1 fluorescence microscope with the Zeiss LSM 700 confocal system and Zeiss ZEN software (Carl Zeiss, Jena, Germany).

After virus infection, transfected C3H10T1/2 cells expressing pEGFP-AQP6 or pEGFP-1 were fixed in 3\% paraformaldehyde and labelled with rabbit anti-CCHFV/Hazara NP antibodies (Andersson et al., 2004) and mouse anti-GFP antibody (Merck Millipore, Darmstadt, Germany), overnight at $4^{\circ} \mathrm{C}$. Then, Alexa Fluor 488- or 568-conjugated secondary antibodies (Life Technologies), were added for labelling. The specimens were mounted on glass coverslips (thickness $0.17 \pm 0.01,13 \mathrm{~mm}$-diameter; Karl Hecht Assistent, Sondheim, Germany) in ProLong Gold antifade reagent (Life Technologies). For confocal imaging, the specimens were examined through a $63 x$ oil immersion objective with NA 1.40 in a Zeiss Axio Observer Z1 fluorescence microscope with the Zeiss LSM 700 confocal system and Zeiss ZEN software (Carl Zeiss).

\section{Phagocytosis assay}

Macrophages on glass cover slips were washed with $\mathrm{KRG}+\mathrm{Ca}^{2+}$, fixed with $4 \%$ paraformaldehyde (Sigma Aldrich) for $20 \mathrm{~min}$ at RT and blocked in 1\% BSA after infection or AHL treatment. To label non-ingested and surface-attached bacteria, the samples were incubated for $1 \mathrm{~h}$ at RT with rabbit anti-Pseudomonas antibodies (\#PAI-73116, Thermo Scientific, Rockford, IL), and with Alexa Fluor 635-conjugated goat anti-rabbit antibodies (Life Technologies). The cells were then permeabilized and stained for $20 \mathrm{~min}$ at RT with Alexa Fluor 568-conjugated phalloidin for cytoskeleton F-actin labelling (Life Technologies). The 
specimens were mounted in ProLong Gold antifade reagent (Life Technologies) and examined through a $63 \times$ oil immersion objectives with NA 1.40 in a fluorescence microscope Zeiss Axio Observer Z1 with confocal system Zeiss LSM700 and Zeiss ZEN software (Carl Zeiss, Jena, Germany).

Completely ingested bacteria were distinguished by their sole GFP fluorescence (green); bound and non-ingested ones were recognized by combined GFP (green) and Alexa Fluor 647 (blue) colour (Paper I Fig 1A). Macrophages containing ingested bacteria were counted as phagocytosis-positive cells (Paper I Fig 1A, shown in white squares and inserts); and macrophages with adherent (Paper I Fig 1A, pointed by white arrows) and/or ingested bacteria were counted as macrophages associated with bacteria. To quantitate, Fiji software (NIH, Bethesda, MD) was used; binding- and phagocytic activities were presented as the percentage of phagocytosis-positive macrophages among total cells.

The pinhole was set to 1 airy unit during all LSCM acquisitions.

\section{Super-resolution microscopy}

In 2014 Stefan W. Hell, Eric Betzig and William E. Moerner were rewarded the Nobel Prize in Chemistry 2014 for their development of super resolution fluorescence microscopy and Stefan W. Hell specifically for the development of Stimulated emission depletion (STED) microscopy in 2000. Eric Betzig and William Moerner were rewarded for their development of single molecule detection microscopy. The basics for several high resolution techniques like PhotoActivated Localisation Microscopy (PALM), Fluorescence Photo-Activated Localisation Microscopy (fPALM) and Stochastic Optical Reconstruction Microscopy (STORM). Altogether, these three scientists, together with Mats Gustafsson who developed Structured Illumination Microscopy (SIM) laid the grounds for the field of nanoscopy.

\section{Structured illumination microscopy}

SIM is a family of visualization techniques where all are based on a periodical illumination of the sample through a sin wave or grid pattern. This illumination imparts variations into the image, lifting high-frequency information into an observable level. A sequence of images is acquired, with the pattern in various positions, and the contrast of each point is then quantified pixel by pixel. Using advanced algorithms an image with greater detail is then constructed. SIM can yield a resolution of around $100 \mathrm{~nm}$, which is an improvement by a factor 2 compared with conventional, diffraction limited LSCM.

The samples prepared for SIM were stained with rabbit anti-AQP9 antibodies (\#ab84828-100, Abcam, UK) and Atto647N (fluorophore for STED) secondary antibodies (Active Motif, Carlsbad, CA), and mounted in ProLong Gold antifade reagent (Life Technologies). The samples were then examined in a fluorescence microscope Zeiss LSM 780 with ELYRA S.1 system (Carl Zeiss, Jena, Germany).

\section{Stimulated emission depletion microscopy}

STED microscopy is based on pattern illumination. One laser beam excites the sample in the focal plane, a second laser is immediately used to selectively, through its doughnut shape, deexcite fluorophores outside the centred spot of the doughnut-shape [235]. This reduces the size 
of the excitation spot and thus the PSF, which improves the resolution. STED nanoscale visualization allows the acquisition and study of subcellular architecture and dynamics at the nanoscale resolution, i.e. 5-10 times higher $(<20-40 \mathrm{~nm})$ resolution than with LSCM.

For STED microscopy the samples were stained as for SIM. The specimens were examined in the Leica TCS SP8 STED 3X super-resolution microscope equipped with two continuous wave lasers at $592 \mathrm{~nm}$ and $660 \mathrm{~nm}$ and a pulsed laser at $775 \mathrm{~nm}$ and a 100×/1.4NA oil immersion objective (Leica Microsystems, Mannheim, Germany).

\section{Image analyses}

Fluorescence intensities, cell sizes and morphologies from live cell imaging, LSCM and STED were measured and quantified using the ImageJ Fiji software (NIH, Bethesda, MD) and LAS AF software (Leica Microsystems, Mannheim, Germany).

Image restoration, deconvolution, of the images was performed using the Huygens software (Scientific Volume Imaging, Hilversum, the Netherlands). Deconvolution of images renders an improvement of the resolution. The technique is based on algorithms used to calculate the maximum of the PSF for each point and then removing out-of-focus signals.

The images acquired with the M4 Holomonitor were analysed using the Hstudio software (Phase Holographic Imaging PHI AB).

\section{Quantitative PCR (qPCR)}

To determine differences in the expression of AQPs, qPCR were performed using GAPDH as reference gene. The GeneJET RNA Purification Kit (\#K0731, Thermo Scientific) or TRIzol (Life Technologies), High capacity RNA-to-cDNA Kit (random hexameres) and the Taqman Fast Universal PCR Master Mix (all from Applied Biosystems, Stockholm, Sweden) were used for extraction, reverse transcription and amplification respectively according to the manufacturer's instructions. The amount of cDNA for the qPCR was set to 50 or $100 \mathrm{ng} / \mathrm{well}$. The master mix of TaqMan Gene Expression Assay Mix (20X, $1 \mu 1 /$ sample, for AQP1, AQP3, AQP4, AQP6, AQP7, AQP8, AQP9, AQP10, AQP11, SLC9A1 or GAPDH (Life technologies)), TaqMan Fast Universal PCR Master Mix (2X) No AmpErase UNG (10 $\mu 1 /$ sample) (all from Applied Biosystems) and RNase free water was placed in the MicroAmp Fast Optical 96-well reaction plate (Applied Biosystems) and cDNA was added to a total volume of $20 \mu \mathrm{l}$. All samples were run in triplicates. The plate was sealed with Optical Adhesive cover (Applied Biosystems) and the PCR was run according to the 7500FAST programme; step $195^{\circ} \mathrm{C} 20 \mathrm{~s}$, step $295^{\circ} \mathrm{C} 3 \mathrm{~s}$, and step $360^{\circ} \mathrm{C} 30 \mathrm{~s}$. Step 2 and 3 were repeated for 40 cycles. The results were analyzed using the 7300 System Software or 7500 System Software v2.3 (Applied Biosystems). The Ct value was used to calculate fold-increase in AQPs and NHE1 compared relatively to the reference gene GAPDH and the set control for that experiment.

\section{mRNA array analysis}

Cells were rinsed with PBS, pH 7.6 and lysed with TRIzol (Life Technologies) to obtain total RNA. The Affymetrix human arrays and mRNA expression profiling were performed by Atlas Biolabs GmbH (Berlin, Germany) to analyse genome wide mRNA expression changes. 


\section{Preparation of total cell lysate, SDS-PAGE and immunoblotting}

Cells were washed and lysed with cold RIPA buffer (1\% NP-40, 1\% deoxycholic acid sodium salt, $0.1 \%$ SDS, $150 \mathrm{mM} \mathrm{NaCl}, 10 \mathrm{mM}$ Tris $\mathrm{pH}$ 7.4, $10 \mathrm{mM}$ EDTA pH 8.0 dissolved in PBS) containing $25 \mathrm{U}$ nuclease (Thermo Scientific), $1 \mathrm{mM}$ phenyl-methyl-sulfonyl-fluoride, $1 \mathrm{mM}$ $\mathrm{Na}_{3} \mathrm{VaO}_{4}, 25 \mathrm{mM} \mathrm{NaF}$ (Sigma), protein inhibitors Complete (Roche Diagnostics, Mannheim, Germany). Cell lysates were homogenized through a 21-gauge needle, centrifuged and the supernatants were collected. The protein concentrations in lysates were measured with the BioRad $D_{C}$ protein assay (Bio-Rad Laboratories, Hercules, CA). The samples were diluted in Laemmli sample buffer at equal protein concentrations, heated for $5 \mathrm{~min}$ at $95^{\circ} \mathrm{C}$ and loaded on 4-12\% SDS-polyacrylamide gels (Lonza, Rockland, ME). After separation, proteins were electrophoretically transferred to a PVDF membrane (Millipore, Bedford, MA). The membranes were blocked and then incubated overnight with rabbit anti-AQP9 antibodies (\#ab85910 Abcam), diluted or mouse anti-GAPDH antibodies (Millipore, Temecula, CA) and consequently with IRDye $800 \mathrm{CW}$ goat anti-rabbit or IRDye $680 \mathrm{CW}$ goat anti-mouse antibodies (LI-COR Biosciences, Cambridge, UK). The signals were detected and quantified by Odyssey CLx and the Image Studio software (LI-COR).

\section{Patient group}

Previously diagnosed collagenous colitis (CC) patients with an ongoing clinically and histologically active disease were included in the study. Active disease was defined as having a mean $\geq 3$ stools/day or a mean of $\geq 1$ watery stool/day during a one week diary registration. [236] Totally 12 patients with active CC were included. Furthermore, we examined a controlgroup obtained from the colonic cancer-screening program. The controls were age-matched $(\mathrm{N}=11)$. All controls had a normal colonoscopy and histology. Controls were not on medications that may influence the mucosa of the bowel, e.g. NSAIDs like 5-ASA. Colonic mucosa biopsies were obtained via endoscopy from the descending colon for experimental research and histological confirmation of CC. All patients were treated with the corticoid steroid budesonide $9 \mathrm{mg}$ daily for 8 weeks. A second sigmoidoscopy was performed when the patient was in clinical remission following the same procedure. Remission was defined as having a mean $<3$ stools/day or a mean of $<1$ watery stool/day during budesonide treatment. All biopsies were placed in Allprotect Tissue Reagent (Qiagen, Sollentunda, Sweden) to preserve and stabilize RNA for downstream PCR analysis.

\section{Immunohistochemistry}

The colonic biopsies were washed, weighed and placed in PBS before fixed in $4 \%$ paraformaldehyde (Sigma Aldrich) for $15 \mathrm{~min}$. Then the biopsies were placed in plastic containers before submerged in $70 \%$ ethanol overnight. The biopsies were then dehydrated in ethanol in increasing concentrations before submerged in Tissue Clear (Histolab, Gothenburg, Sweden) with following paraffin baths $2 \times 30 \mathrm{~min}$ and placed in paraffin overnight.

A Leica RM2255 fully automated rotary microtome (Leica) was used to prepare the tissue sections at $5 \mu \mathrm{m}$. The sections were placed on $25 \times 75 \times 1.0 \mathrm{~mm}$ Superfrost plus microscopy slides (Thermo scientific) and fixed to the glass at $60^{\circ} \mathrm{C}$ overnight. 


\section{Haematoxylin/eosin staining}

The sections were deparaffinised in Tissue clear (Histolab) before hydrated in consecutively decreasing concentrations of ethanol before placed in tap water. Hematoxylin staining was performed for $3 \mathrm{~min}$ before the samples were moved to tap water with a drop of ammonia. The samples were put in $95 \%$ ethanol for 30 s before 30 s of eosin staining. The samples were rinsed repeatedly before dehydrated in consecutively increasing concentration of ethanol and then Tissue clear (2x2min). The samples were mounted with Pertex and visualised using an Olympus BX51 light microscope with a colour CCD camera.

\section{Statistical methods and analyses}

\section{Paper I}

Data are presented as mean $\pm \mathrm{SE}$. Data from the phagocytosis assays were analysed using paired, two-tailed $t$-test. Whole cell and over the cell AQP9 fluorescence intensities were analysed using unpaired, two-tailed $t$-test when comparing control vs. infected samples and one-tailed $t$-test for comparison of wild type and lasI-/rhlI- mutant.

\section{Paper II}

Data on optical volume are presented as a percent of change, the values represent a 7-point moving averages of the means \pm standard error (SE), and significant differences were analysed by two-way ANOVA and Bonferroni's posttest. Data in all other graphs were presented as mean \pm SE. Results from live 2D imaging were analysed using Student's $t$-test. The qPCR experiments were analysed by two-way ANOVA and Bonferroni's posttest. Data from immunoblotting were analysed by one-way ANOVA-Friedman and Dunn's multiple comparison test. The whole cell fluorescent intensity measurements were analysed by one-way ANOVA and Dunnett's multiple comparison test and approximated cell area and length in AQP9-stained macrophages were analysed using one-way ANOVA.

\section{Paper III}

Data in the graphs are presented as mean \pm SE. Statistical analyses were based on two-tailed Student's $t$-test or Mann-Whitney test.

\section{Paper IV}

Data are presented as median $\pm \max / \min$ (interquartile range). Data comparing the patient group with the control were analysed using Mann-Whitney test. Data comparing within the patient group comparing the untreated with the budesonide treated samples were analysed using onetailed, Wilcoxon matched-pairs signed rank test.

$P$-values $<0.05(*),<0.01(* *)$, and $<0.001(* * *)$ were considered significant. 


\section{RESULTS AND DISCUSSION}

\section{Paper I}

\section{"Pseudomonas aeruginosa lasl/rhll quorum sensing genes promotes phagocytosis and AQP9 redistribution to the leading and trailing regions in macrophages"}

Pseudomonas aeruginosa utilizes its quorum sensing system for example communication, establishment of infection and for protection against host immune responses by transcription of virulence factors. Previous data from our group and others have shown how this AHL communication affect human host cells such as migration and phagocytosis $[4,147,152,155$, $156,188,225,237,238]$. In cell motility the aquaporins play an important role for the formation membrane protrusions $[17,40,58,77,80]$. Here we therefore studied the impact of lasI/rhlI genes in P. aeruginosa on macrophage phagocytosis and AQP9 expression. This was carried out using immunoblotting, confocal- and super resolution microscopy.

More effective binding and phagocytosis of wild type $P$. aeruginosa than of its lasl-/rhllmutant

Human primary macrophages were infected with GFP wildtype $P$. aeruginosa PAO1 or its lasIIrhlI- mutant at MOI1, 10 or 100 for $1 \mathrm{~h}$. Extracellular bacteria were stained with $P$. aeruginosa antibodies (blue, Figure 1A) and phagocytosis was quantified using LSCM (Paper I Fig.1A). Bound bacteria were identified as GFP-positive combined with $P$. aeruginosa staining while ingested bacteria were identified by sole GFP. Quantification of phagocytosis revealed a significantly more effective binding and phagocytosis of wild type $P$. aeruginosa bacteria at MOI10, when compared to lasI-/rhlI- mutant lacking $\mathrm{C}_{4}$-HSL and $3 \mathrm{O}-\mathrm{C}_{12}$-HSL (Paper I, Fig. 1BC). At MOI10 the wild type bacteria elicit 1.42 - and 1.86 -fold greater binding and phagocytosis respectively. At MOI1 and 100 similar pattern for stronger responses for the $P$. aeruginosa wild type were observed but these differences in responses were not significant (Paper I, Fig. 1BC).

To elucidate if phagocytosis could be functionally complemented by pre-treatment with $\mathrm{C}_{4}$ HSL and 3O-C $\mathrm{C}_{12}$-HSL we stimulated the macrophages with synthetic AHLs before infection. One out of four independent experiments showed an elevated phagocytosis in cells infected with the mutant and the difference between the wildtype and mutant was equalized (Paper I, Fig 2). A functional QS signal system may be sensed and recognized by macrophages as a danger signal and thereby initiates a stronger phagocytic response. The minor discrepancy seen here, with only partial elevation of phagocytosis in $\mathrm{C}_{4}$-HSL and $3 \mathrm{O}-\mathrm{C}_{12}$-HSL stimulated macrophages suggests that other factors directly or indirectly controlled by lasI/rhlI may play a more significant role in this event. AHLs have been shown to affect migration and phagocytosis in a time- and does-dependent manner [146, 239, 240]. The differences observed for the different MOIs could in part be explained by the difference in concentrations of AHL. Donor-specific variations of the macrophages response capabilities, including differences in migration and phagocytosis could also influence the response [241, 242]. 


\section{Increased AQP9 protein levels $P$. aeruginosa infected macrophages}

The human leukocytes must quickly change their morphology and volume in order to migrate into tissues. This is largely driven by transmembrane water fluxes through AQPs, primarily AQP9 in leukocytes [31, 40, 58]. Since phagocytosis of wild type P. aeruginosa was increased compared to its lasI-/rhlI- mutant, we addressed whether AQP9 was involved in this process by looking at the expression levels of AQP9 in macrophages after P. aeruginosa infection. Using immunoblotting with GAPDH as a loading control (Paper I, Fig. 3A) and a subsequent quantification of the density of specific bands (Paper I, Fig. 3B) we observed a significant increase of the AQP9 expression in P. aeruginosa infected cells at all MOIs compared to uninfected controls. The wild type bacteria seemed to cause a more pronounced increase than the QS-mutant but no significant differences were found.

\section{P. aeruginosa affects cell morphology and the cellular distribution of AQP9}

The cellular distribution and dynamics of AQP9 have been shown to be very important for promoting membrane protrusions and consecutive formation of filopodia, blebs and lamellipodia $[15,31,40]$. Using confocal microscopy, we therefore investigated the cellular distribution and localisation of AQP9 in infected macrophages (Paper I, Fig. 4A). Compared to uninfected controls, with low levels of AQP9 in the cytoplasmic region, P. aeruginosa infected cells had a remarkable alteration in both intensity and localisation of AQP9. Whole cell AQP9 fluorescence intensity was significantly higher in all infected macrophages compared to control cells and wild type bacteria showed significantly higher whole-cell fluorescence compared to the lasI-/rhlI- mutant at MOI10 (Paper I, Fig. 4B). Regarding the cellular distribution, we observed more AQP9 in the front and rear end of infected cells, whereas the control cells displayed a more evenly distributed profile (Paper I, Fig. 4CD). Quantification of cell morphology revealed a significant increase of the cell area for wild type infected cells compared to controls (Paper I, Fig. 5A) and a significant increase in cell length for both wild type and mutant infected cells for the lower MOIs (Paper I, Fig. 5B).

To further study the alterations in AQP9 distribution we used a novel super-resolution imaging technique, i.e. Stimulated Emission Depletion (STED) microscopy. Using STED microscopy we gained a further increase in resolution to around 20-40nm. After infection with $P$. aeruginosa we observed a more distinct AQP9 localisation in the cytoplasm at the leading and trailing edges as well as protruding structures. The wild type strain triggered a pocket-like accumulation of AQP9 around intracellular bacteria (Paper I, Fig. 6AB) while lasI-/rhlI- mutant strain induced a more modest effects on the AQP9 nano-architecture (Paper I, Fig. 6AB).

\section{Water flux inhibitors show small effects on the phagocytosis of $P$. aeruginosa}

Regarding the effects seen on the expression and localisation of AQP9 in P. aeruginosa infected macrophages we sought to elucidate the effects of AQP inhibition. Macrophages were pretreated with 1 or $5 \mu \mathrm{M} \mathrm{HgCl}_{2}$ to generally block AQPs and $20 \mu \mathrm{M}$ HTS13286 to specifically inhibit AQP9 before infection. The phagocytosis of bacteria was only partly decreased by mercury (Paper I, Fig. 7A). No inhibition of phagocytosis was observed with AQP9 specific inhibitor (Paper I, Fig. 7B). But looking at the responses from individual donors 3 out of 5 donors showed an inhibition of the phagocytosis in the $5 \mu \mathrm{M} \mathrm{HgCl}_{2}$ treated samples. These data 
suggest that water transport through AQPs only partly facilitates the phagocytosis process of $P$. aeruginosa. This indicated that other crucial cellular signaling pathways also are engaged in the process.

To conclude we have demonstrated how phagocytosis of $P$. aeruginosa by macrophages is more effective when its QS genes lasI and rhlI and thus the transcription of $\mathrm{C}_{4}-\mathrm{HSL}$ and $3 \mathrm{O}-\mathrm{C}_{12}-\mathrm{HSL}$ and down-stream virulence factors, are fully functional. Infection with $P$. aeruginosa also lead to an increased AQP9 expression and re-localisation to the leading and trailing edges in the cells, an increased cell area and length. In our experiments, bacteria with a complete QS system contributed more to these processes (Fig. 4). Hence, adding a new player, AQP9 to the infection and inflammatory events and inter-kingdom signaling between host and P. aeruginosa.

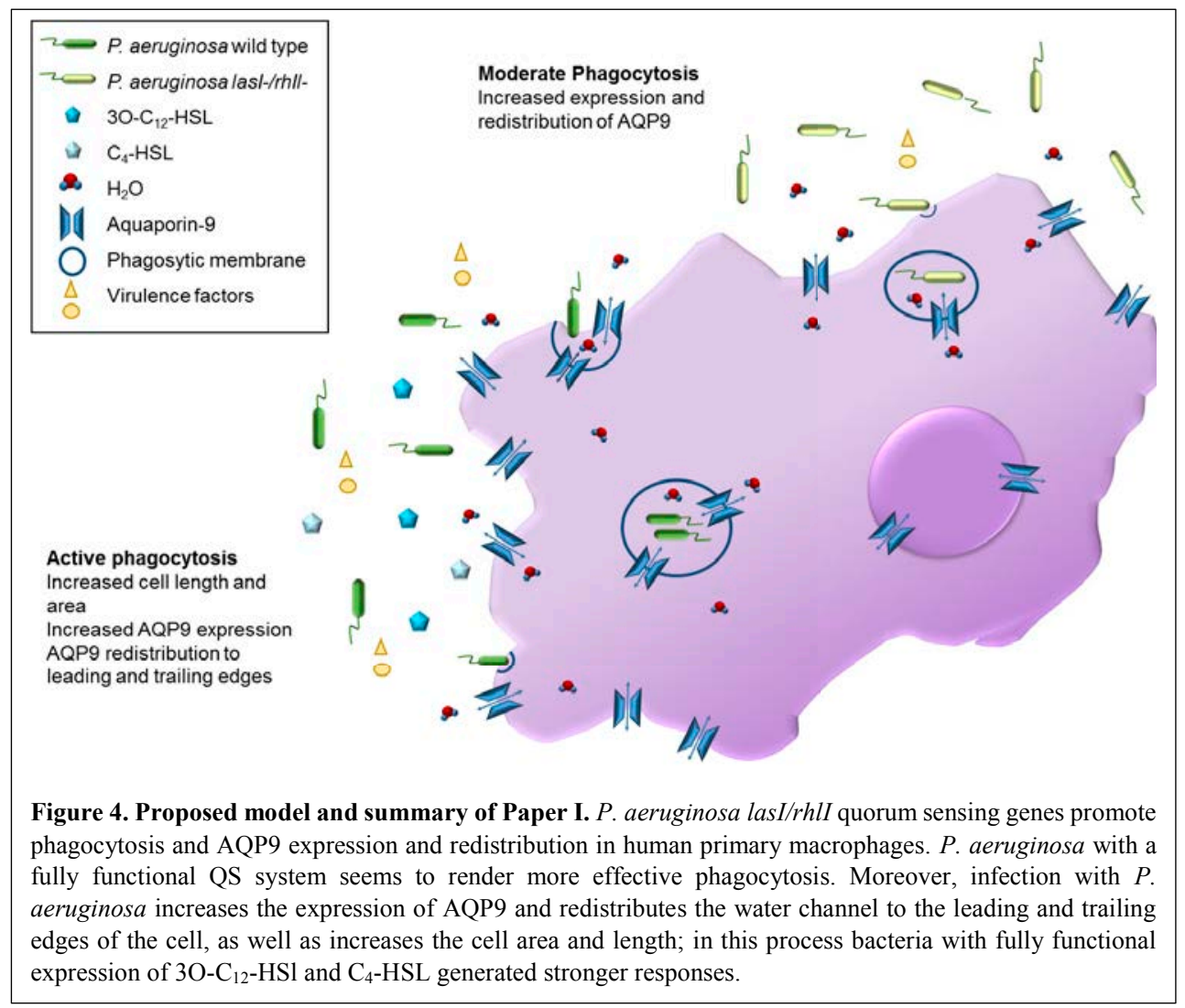




\section{Paper II}

\section{"Pseudomonas aeruginosa N-3-oxo-dodecanoyl-homoserine lactone elicits changes in cell volume, morphology and AQP9 characteristics in macrophages"}

The $P$. aeruginosa AHL $3 \mathrm{O}-\mathrm{C}_{12}$-HSL can diffuse into cells $[153,154]$ and modulate immune responses $[152,155,156]$. To further investigate the impact of $P$. aeruginosa QS on host cells and assess in greater detail the bacteria-host cell communication, we investigated the effects of $P$. aeruginosa $3 \mathrm{O}-\mathrm{C}_{12}-\mathrm{HSL}$ on cell morphology, area, volume and AQP9 characteristics of human primary macrophages. This was achieved using quantitative PCR, immunoblotting, live 2D and 3D imaging along with laser scanning confocal and nanoscale imaging.

\section{Cell area and protrusive activity is increased in $30-\mathrm{C}_{12}-\mathrm{HSL}$ treated macrophages}

$P$. aeruginosa $3 \mathrm{O}-\mathrm{C}_{12}-\mathrm{HSL}$ can stimulate both chemotaxis and phagocytosis in leukocytes [4, $144,146,240]$, which both are processes highly dependent on dynamic changes in cell size and morphology. Using 2D live imaging, we observed $3 \mathrm{O}-\mathrm{C}_{12}$-HSL treated macrophages over time, allowing us to quantify cell area and protrusive activity. Generally the cell area was decreased and later increased in all three (controls, $10 \mu \mathrm{M}$ and $50 \mu \mathrm{M}$ ) groups (Paper II, Fig. 1A), this reflects the classical cycle of cell retraction, spreading, and extension during macrophage rest as well as their spontaneous movements. Treatment with $50 \mu \mathrm{M} 3 \mathrm{O}-\mathrm{C}_{12}-\mathrm{HSL}$ rendered a significant increase in cell area in macrophages in contrast to controls and $10 \mu \mathrm{M} 3 \mathrm{O}-\mathrm{C}_{12}-\mathrm{HSL}$ (Paper II, Fig. 1A). Also, as described in previous paper (Paper I) we observed a difference in the response in the individual donors (Paper I, suppl. Fig.1). Tracing the cells demonstrated that control macrophages maintained a similar pattern of morphology over time whereas macrophages treated with 10 and $50 \mu \mathrm{M} 3 \mathrm{O}-\mathrm{C}_{12}$-HSL showed short-term shape fluctuations between polarity and rounding as well as typical protrusive events (Paper II, Table 1, Suppl. Table 1). Next we investigate how blocking of AQP9 affected the morphology of the macrophages. Treatment with $25 \mu \mathrm{M}$ HTS13286 alone resulted in a slight cell rounding with a significant effect at $15 \mathrm{~min}$ as well as an inhibited fluctuation in polarization and protrusions (Paper II, Table 1, Suppl. Table 1). The inhibition also prevented of cell area increases (Paper II, Fig. 1B). Following stimulation with $3 \mathrm{O}-\mathrm{C}_{12}-\mathrm{HSL}$, the area of the cells was smaller at all time points when combined with the HTS13286 inhibitor, compared to $3 \mathrm{O}-\mathrm{C}_{12}$-HSL treatment alone (Paper II, Fig. 1B). Thus 3O-C $12-\mathrm{HSL}$ provokes a quick expansion of cell area and changes in morphology in macrophages and these processes are partly driven by AQP9.

\section{$30-\mathrm{C}_{12}-\mathrm{HSL}$ enhances cell volume in macrophages}

Since we observed a significant increase in cell area in macrophages treated with $3 \mathrm{O}-\mathrm{C}_{12}-\mathrm{HSL}$, we wanted to assess if parallel volume changes may occur. Using 3D holographic imaging we could confirm that the observed changes in area correspond to an optical volume increase in 3O-C 12 -HSL-stimulated macrophages (Paper II Fig. 2). Here we could also observe significant volume fluctuations in the $10 \mu \mathrm{M}$ treated macrophages compared to the controls (Paper II, Fig. 2). 


\section{$30-\mathrm{C}_{12}-\mathrm{HSL}$ increases the expression of AQP9 in macrophages}

Based on previous work in our lab [15, 31, 48] we have shown the importance of AQP9 in leukocyte migration. Since macrophages change their area and volume in response to $3 \mathrm{O}-\mathrm{C}_{12}-$ HSL we wanted to investigate how the expression of AQP9 was affected. Thus we analysed AQP9 mRNA expression by qPCR and protein expression using immunoblotting with GAPDH as a reference gene and loading control. Generally treatment with $3 \mathrm{O}-\mathrm{C}_{12}-\mathrm{HSL}$ at 10,50 and $100 \mu \mathrm{M}$ for 1, 4 and $24 \mathrm{~h}$ respectively generated an increase in both AQP9 mRNA and protein levels (Paper II, Fig. 3ABC). A significant increase in mRNA was seen at $50 \mu \mathrm{M}$ after $4 \mathrm{~h}$ of stimulation with an almost 2-fold increase. Significant increases in the protein expression were detected at $50 \mu \mathrm{M}$ for $1 \mathrm{~h}, 100 \mu \mathrm{M}$ for $4 \mathrm{~h}, 10 \mu \mathrm{M}$ and $50 \mu \mathrm{M}$ for $24 \mathrm{~h}$. Thus, treatment with $3 \mathrm{O}-\mathrm{C}_{12}$-HSL increases the expression of AQP9.

\section{$30-\mathrm{C}_{12}-\mathrm{HSL}$ changes cellular morphology and redistributes AQP9 in macrophages}

Next we examined whether $3 \mathrm{O}-\mathrm{C}_{12}$-HSL could affect the cellular localisation of AQP9 using LSCM. The control cells displayed a low and diffuse expression of AQP9 while cells after treatment with $3 \mathrm{O}-\mathrm{C}_{12}$-HSL showed a significant increase in the AQP9 whole-cell fluorescence intensity (Paper II, Fig 4AB). Measuring the intensity over the cells in the direction of polarisation revealed a pronounced and significant redistribution of AQP9 to the leading and trailing edges of the cells (Paper II, Fig 5AB).

Quantifying the cell area using the LSCM images we found a significant increase in the cell area after $24 \mathrm{~h}$ of stimulation with 50 and $100 \mu \mathrm{M}$ (Paper II, Fig. 6A). This inconsistency with the 2D data (Paper II, Fig. 1A) could depend on the different methods used to measure the cell area: confocal imaging of AQP9 stained cells and over longer time periods vs live cell imaging at lower resolution. Cell length was not affected by 3O-C $12-\mathrm{HSL}$ (Paper II, Fig. 6B).

The AQP9 distribution and architecture changes at nanoscale resolution in response to $3 \mathrm{O}-\mathrm{C}_{12}-\mathrm{HSL}$

To study the detailed redistribution of AQP9 in the stimulated macrophages we used stimulated emission depletion (STED) microscopy. Since the macrophages change their optical volume, (Paper II, Fig. 2), AQP9 levels (Paper II, Fig. 3A) and cellular distribution (Paper II, Fig. 4, 5) already at $10 \mu \mathrm{M}$ we decided to proceed to investigate how low concentration of $3 \mathrm{O}-\mathrm{C}_{12}-\mathrm{HSL}$ affects the nano-scale structural architecture of AQP9. We observed a more distinct AQP9 localisation in the peripheral regions in the vicinity of the leading- and trailing edges of the cell in stimulated macrophages compared to control (Paper II, Fig. 7AB). By using Huygens deconvolution we could further improve the resolution of the images (Paper II, Fig. 7 A). Measuring the intensity over the cell from the nuclear area to the edge revealed a distinct profile and accumulation of AQP9 at the edge regions in comparison to the dilution controls (Paper II, Fig. 7B). In the lamellipodial area in the stimulated cells we found distinct longitudinal wave patterns of AQP9 intensity. These waves were localised perpendicular to the direction of the assumed cell movement (Paper II, Fig. 8A-C), thus identifying regions of AQP9 compression and thinning. 
Cell swelling as a response to bacterial QS molecules could be a danger signal and a signal to prepare for migration. Cell swelling in itself can cause an inflammatory response through the activation of the NALP3 inflammasome [59, 243], leading to the production of the proinflammatory cytokine IL-1 $\beta$. Bacterial $3 \mathrm{O}-\mathrm{C}_{12}$-HSL upregulate IL-1 $\beta$ [244]. Bleb and other membrane protrusions are important for migration through 3D environments [30] and has been shown to depend on water fluxes through AQP9 in leukocytes [183].

Taken together the data presented here shows that $P$. aeruginosa $30-\mathrm{C}_{12}-\mathrm{HSL}$ plays an important role in the manipulation of AQP9 expression and characteristics, and thereby via water fluxes through AQP9 water channels affect cell area, volume and protrusive activity (Fig.5). These are all processes of importance for macrophage function during infections. These interactions likely have an effect on the early initiation of infection and inflammation as well as the development of disease.

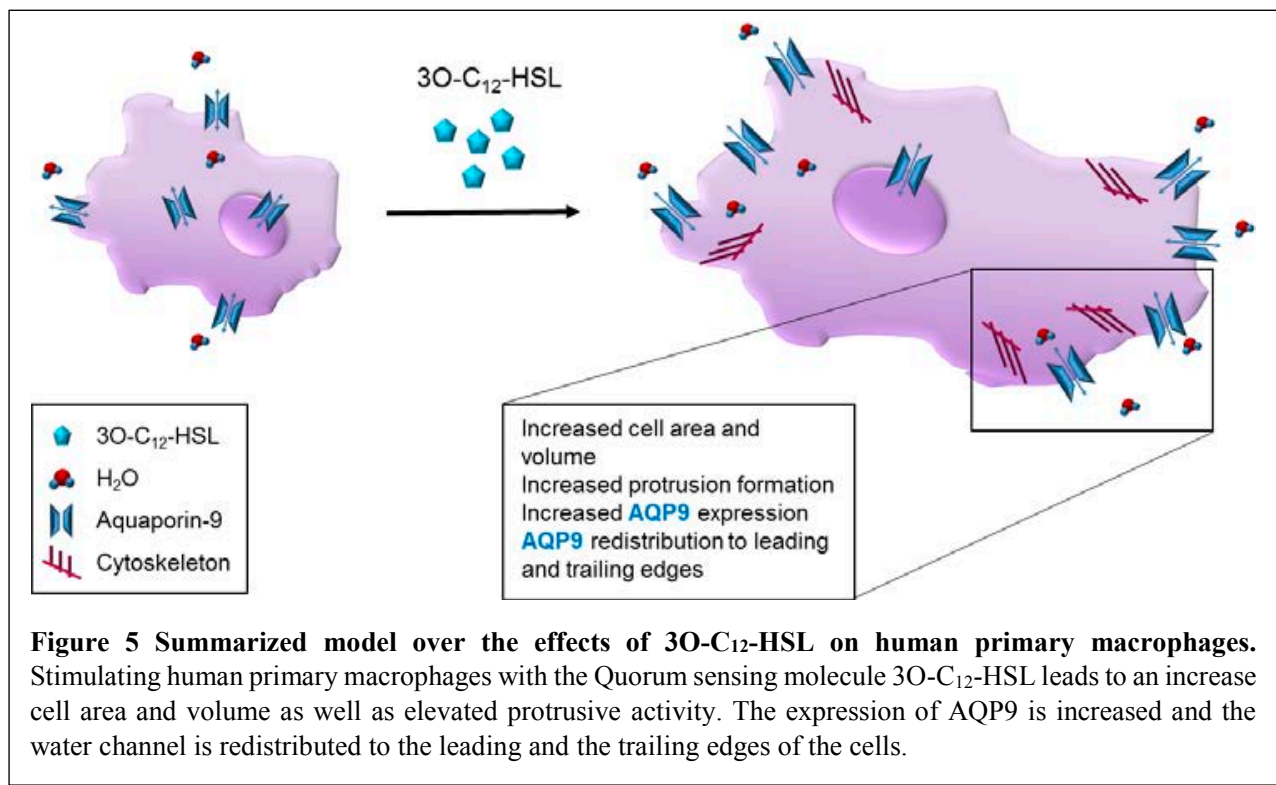




\section{Paper III}

\section{"Protective role of host aquaporin 6 against Hazara virus, a model for Crimean-Congo haemorrhagic fever virus infection"}

Crimean-Congo haemorrhagic fever virus (CCHFV) infection leads to a severe disease with haemorrhages in the acute phase and a high mortality rate $[165,166]$. Currently there are only a few reports on the importance of AQPs in viral infections [186, 187], which prompted us to further assess the consequences of virus versus water channels. The intracellular AQP6 mediates vesicle transport in cells and acts as an ion channel. Using GFP-AQP6 expressing host cells, Hazara virus, immunofluorescent assays for virus detection and epifluorescent and confocal microscopy we aimed to study the effects of virus infection on AQP6 expression and distribution and the importance of AQP6 expression on virus infectivity in host cells.

\section{CCFHV and Hazara virus infection reduces AQP6 expression}

A C3H10T1/2 transiently expressing AQP6 cell line was generated to investigate the cellular localisation and distribution of AQP6. Epifluorescent imaging revealed AQP6 located in the vicinity of the plasma membrane, in the perinuclear area and in cytoplasmic vesicle membranes (Paper III Fig 1.). The empty GFP-vector controls showed diffuse localisation in the cytoplasm. Our observed localisation of AQP6 correlate with previous reported studies [52, 55, 245].

Next, we examined the effects of Hazara virus infection on the AQP6 expression in C3H10T1/2 cells harbouring GFP-AQP6. Hazara virus was found in the perinuclear area of the infected cells (Paper III Fig 1.), consistent with previous reports regarding CCHFV [232]. After Hazara infection at MOI100 the GFP-AQP6 expressing cells showed significantly lower AQP6 whole cell fluorescence intensity (Paper III, Fig. 2A) and AQP6 nuclear membrane fluorescence intensity (Paper III, Fig. 2B). Since the AQP6 distribution was reduced, we expected that parallel cell size changes likely driven by water flux through the AQP occur. Indeed, fluctuations in cell area were observed after Hazara infection (Paper III, Fig. 2C) and the AQP6 fluorescence per cell area was significantly lower after infection at MOI100 compared to the controls (Paper III, Fig. 2D). Hazara virus is believed to be a good experimental model for CCHFV. The two viruses are related and show a high homology but Hazara virus does not cause disease in mammals making it suitable for studies without access to P3 laboratories. Though it should be noted that there are some differences between the two viruses e.g. they only exhibit $14 \%$ and $29 \%$ amino acid and nucleotide sequence homology, respectively [246]. We therefore performed mRNA analysis regarding AQP6 expression in CCHFV infected SW13-cells. At $48 \mathrm{~h}$ post-infection at MOI1 AQP6 mRNA expression was reduced by 30 -fold compared to uninfected control (data not shown in figures). Thus, both Hazara and CCHFV virus infections reduce AQP6 expression in human cells.

\section{AQP6 overexpression reduces the infectivity of Hazara virus}

We hypothesized that AQPs have a protective role in viral infection through direct or indirect interaction with the cytoskeleton, thereby regulating cellular events such as vesicle transport and apoptosis. To test this we investigated whether AQP6 overexpression affects the yields of Hazara virus in infected cells. Quantifying Hazara virus yields in supernatants from GFP-AQP6 
expressing cells showed a reduction of $32 \%$ and $55 \%$ at MOI1 and 100 respectively compared to non-transfected and empty-vector transfected cells (Paper III Table 1). By analysing the correlation between Hazara virus fluorescence intensity and GFP-AQP6 fluorescent intensity using LSCM we could observe a higher expression of viral nucleo-capsid protein (NP) in cells of low or mediate AQP6 expression (Paper III, Fig. 3). Most cells overexpressing AQP6 were likely not infected as no viral NPs were detected. Expression of the empty GFP vector only slightly affected the virus infectivity. The number of cells expressing both Hazara virus and GFP-AQP 6 was reduced by 55\% and 48\% for cells infected at MOI1 and MOI100, respectively, compared to cells infected with Hazara virus and transfected with the GFP-empty vector (Paper III, Table 2). These results indicate that the inhibition of virus progeny seen in cells expressing AQP6 (Paper III, Table 1) most probably is due to the reduction in number of infected cells. Thus we have found and added a new possible mechanism that host cells use to protect and fight viral infections and a new role for AQP6. AQPs have previously been shown to be involved in virus infections. Towne et al demonstrated how the decreased levels of AQP1 and 5 in pulmonary adenoviral infection were associated worsened lung oedema [186]. Moreover AQPs have been shown to be involved in the remodelling of the cytoskeleton $[15,40]$ and an intact cytoskeleton is required for CCHFV entry, assembly and release [170, 232].

In conclusion we show that overexpression of AQP6 decreases the yield of viral particles, suggesting a reduced infectivity of Hazara virus (Fig. 6 and Paper III, Fig. 4). However, the Hazara virus could overcome this protective capacity of AQP6 by reducing the cellular and perinuclear distribution of AQPs in host cells through a high viral load.

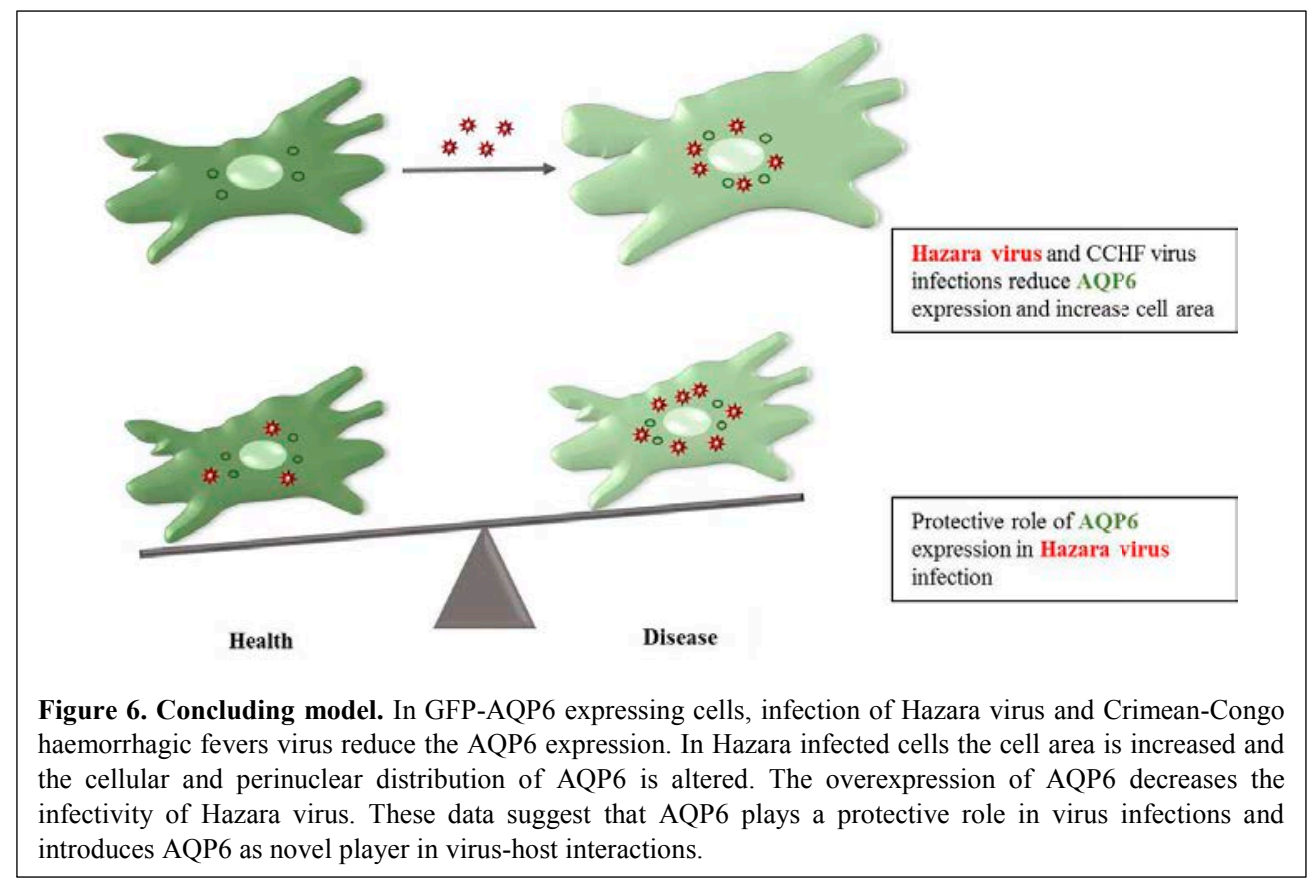




\section{Paper IV}

\section{"Aquaporin expression and localisation in colonic biopsies from collagenous colitis patients"}

Collagenous colitis patients suffer from severe watery diarrhoea and thus markedly reduced quality of life. Treatment with the glucocorticoid budesonide effectively reduces stool frequency and improves stool consistency. But the underlying mechanisms for both the development of the disease and the mechanisms of treatment are poorly understood. We therefore investigated the expression of AQPs in colonic biopsies from CC patients with active disease and in clinical remission under budesonide treatment and compared with healthy controls. Using quantitative PCR we looked at the expression of AQP1, AQP3, AQP4, AQP6, AQP7, AQP8, AQP9, AQP10 and AQP11. We also investigated the sodium/ hydrogen exchanger 1 (NHE1). NHE1 is involved in cellular events important for normal intestinal function such as cell migration [247] and volume regulation [248].

Collagenous colitis (CC) patients display a decreased expression of AQP1, 8 and 11

In a pilot study performed on colonic biopsies from healthy controls and $\mathrm{CC}$ patients $(n=6)$ we did not detect mRNA encoding for AQP4, 6, 7, 9 and 10 and the channels were then excluded from further analysis.

In total we investigated biopsies from $12 \mathrm{CC}$ patients ( 10 women, 2 men, with a mean age of 57 years) and 11 healthy controls (mean age 55 years). In active disease the mean bowel movements were 6.8 (range 5-10)/day of watery consistency (Bristol stool scale typ7). The qPCR analysis revealed significantly decreased levels of mRNA encoding for AQP1, 8 and 11 in CC patients with active disease compared to controls (Paper IV Fig.1 A, C, D). Although present in all samples, the expression of AQP3 did not change significantly (Paper IV Fig.1 B).

\section{Treatment with budesonide restores expression of AQPs}

All patients went into clinical remission under budesonide treatment with mean bowel movements decreasing to 1.4 (range 2.5-1)/day. Analysing the biopsies obtained from the patients under budesonide treatment and clinical remission revealed no significant difference in the expression levels of AQP1 and 11 when compared to the controls, indicating a restored expression level of the two proteins (Paper IV Fig.1 A, D). For AQP8 there was still a significant decrease in the expression compared to controls (Paper IV Fig.1 C), but when comparing the patient group before and during budesonide treatment we observed a significant increase in the mRNA levels for AQP8 during treatment (Paper IV Fig.2C). AQP3 has been shown to be upregulated in response to glucocorticoid treatment [249] although we were unable to detect significant decreases in the expression of AQP3 during active disease, there is clearly a trend towards increasing mRNA levels in the patient group during treatment (Paper IV Fig.1 B).

During budesonide treatment MC patients show a marked improvement of clinical symptoms but histologically they still show increased infiltration of white blood cells, and the collagenous layer in CC is still present $[207,210,250]$. Here we show that patients during budesonide 
treatment normalise and significantly increase their AQPs expression (Paper IV Fig.2A, C, D), which suggest an involvement of restored water channel expression as a mechanism of budesonide treatment.

\section{mRNA expression of the sodium/hydrogen exchanger NHE1 is reduced in CC patients}

Analysis of NHE1 mRNA in colonic biopsies from CC patients revealed a significant decrease in patients during active disease compared to controls (Paper IV Fig 3A). NHE1 follows the same pattern as AQP8 with persistently lower levels of expression in the patients during budesonide treatment compared to controls. However, as for AQP8, there was a significant increase in NHE1 expression when comparing mRNA levels within the patient group before and during treatment (Paper IV Fig 3B).

Maintaining a healthy epithelial layer is likely difficult with a dysregulated expression of both NHE1 and AQPs which could result in a more leaky gut and the diarrhoea seen in MC. The cause of MC is unknown. Risk factors that include age, the use of proton-pump inhibitors and NSAIDs have been identified to increase the risk of MC [216, 251]. Stress is a factor that some people find affects their bowel movements and sometimes results in diarrhoea. In cultured rat epithelial cell it has been shown that the expression of AQPs is altered in response to stress [252]. The expression of AQP1, 9 and 11 was increased in response to hypertonic stress and AQP8 and 11 were also affected by ischemic stress. These alteration of the expression was transient regarding the ischemic stress indicating that temporary alteration of the AQPs expression can be resolved. We hypothesise that an unresolved dysregulation of AQPs lays the foundation for the development of chronic diarrhoeal inflammatory diseases. Both hypotonicity and hypertonicity have been shown to influence the translocation of AQPs [43]. It is likely that in $\mathrm{MC}$ the diarrhoea creates an extreme dysregulation in the tonicity leading to a translocation of AQPs which together with an altered expression rate leads to a vicious circle of more watery diarrhoea.

To further elucidate the AQPs dynamics during $\mathrm{CC}$, we are currently performing immunohistochemistry to assess the protein expression and distribution of the channels. We are focusing primarily on the AQPs showing larger variations on transcriptional level (AQP1, 8 and 11) but since translocation of AQPs is an important part of normal functioning of water homeostasis $[43,253]$, we will also assess the moderate or unaffected AQPs. 
In conclusion we show for the first time a down regulation of AQP1, 8 and 11 and NHE1 in CC patients during active disease compared to healthy controls. We also demonstrated how budesonide treatment leads to a restored and increased expression levels of AQPs. Based on our preliminary data we have developed a hypothetical model (Fig. 7) for the expression and role of AQPs in collagenous colitis. Taken together the results indicate a contribution of AQP expression levels in the diarrhoeal mechanisms of CC.

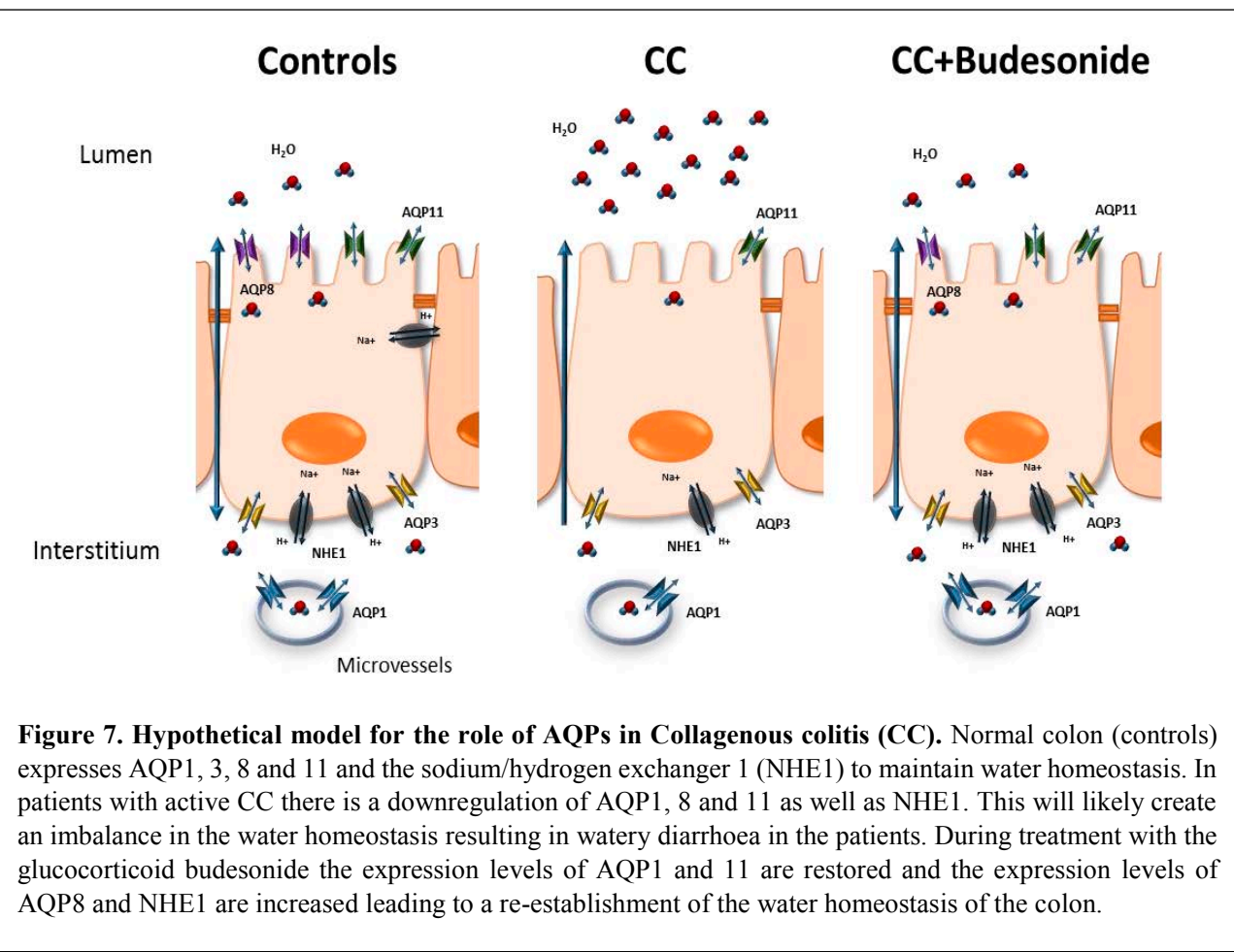




\section{SUMMARY}

P. aeruginosa with a complete QS system elicits a stronger phagocytosis response in human macrophages than the lasI-/rhlI- mutant lacking both $\mathrm{C}_{4}-\mathrm{HSL}$ and $3 \mathrm{O}-\mathrm{C}_{12}-\mathrm{HSL}$.

Infection with $P$. aeruginosa increases the expression of AQP9 and translocates AQP9 to the leading and trailing edges of human macrophages. $P$. aeruginosa with a complete QS system elicits stronger cellular responses compared to the lasI-/rhlI- mutant.

Macrophages increase the expression of AQP9 in response to the QS molecule 3O-C 12 -HSL.

$3 \mathrm{O}-\mathrm{C}_{12}$-HSL re-localises AQP9 to the leading and trailing edges of macrophages.

Infection with $P$. aeruginosa as well as treatment with $3 \mathrm{O}-\mathrm{C}_{12}-\mathrm{HSL}$ affects the nano-structural architecture of AQP9 localisation.

Infection with Hazara virus and Crimean-Congo haemorrhagic fever virus reduce AQP6 expression.

The infectivity of Hazara virus is diminished when AQP6 is overexpressed, thus an overexpression of AQP6 yields cellular protection in infection with Hazara virus.

In colonic biopsies from microscopic colitis (MC) patients, there is a decrease in the expression of AQP1, 8 and 11 compared to control individuals.

During budesonide treatment, the expression levels of AQP1 and 11 are restored, and comparisons within the patient group revealed a significant increase in the expression of AQP8.

In $\mathrm{MC}$, the sodium/hydrogen exchanger NHE1 is down-regulated. The expression is significantly increased during budesonide treatment, close to the expression levels of the control samples.

Taken together, these results put AQP6 and AQP9 as mechanistic players in infection and immune responses and presents the decrease in expression of AQPs as a potential diarrhoeal mechanism in microscopic colitis as well as a recovery mechanism during budesonide treatment. 


\section{CONCLUDING REMARKS}

In response to infectious and inflammatory cues, a dysregulation of the aquaporins occur in human immune and epithelial cells. The diverse roles for AQPs in protection and response to different infections add an important piece to the puzzle of host-pathogen communications, and opens up opportunities regarding investigating specific AQP modulation as a future treatment option.

In the inflammatory bowel disease, collagenous colitis, the AQPs are downregulated in the colon compared to healthy controls. This indicates a role for AQPs in the development and outcome of the disease. The normalisation in the AQP expression levels following treatment with budesonide suggests a new molecular mechanism of glucocorticoid treatment.

The general conclusion for this thesis can be comprised to that there is an effect on the expression of AQPs in bacterial and viral infections as well as a dysregulation of AQPs in the inflammatory disease microscopic colitis.

The results presented in this thesis emphasize AQPs as pivotal players in infections and inflammation. Future studies need to concentrate on the underlying mechanisms of pathology to unravel signalling pathways important in the regulation of AQP expression and functioning in order to specifically pinpoint possible new targets for drug development. 


\section{REFERENCES}

1. Ignacio, A., et al., Innate Sensing of the Gut Microbiota: Modulation of Inflammatory and Autoimmune Diseases. Frontiers in immunology, 2016. 7: p. 54.

2. Kataoka, K., The intestinal microbiota and its role in human health and disease. The journal of medical investigation : JMI, 2016. 63(1-2): p. 27-37.

3. Soares, J.A. and B.M.M. Ahmer, Detection of acyl-homoserine lactones by Escherichia and Salmonella. Current opinion in microbiology, 2011. 14(2): p. 188-193.

4. Karlsson, T., et al., $\mathrm{N}$-Acylhomoserine lactones are potent neutrophil chemoattractants that act via calcium mobilization and actin remodeling. J Leukoc Biol, 2012. 91(1): p. 15-26.

5. Bylund, J., et al., Exopolysaccharides from Burkholderia cenocepacia inhibit neutrophil chemotaxis and scavenge reactive oxygen species. J Biol Chem, 2006. 281(5): p. 2526-32.

6. Hansch, G.M., et al., The extracellular polymer substance of Pseudomonas aeruginosa: too slippery for neutrophils to migrate on? Int J Artif Organs, 2008. 31(9): p. 796-803.

7. Christiaansen, A., S.M. Varga, and J.V. Spencer, Viral manipulation of the host immune response. Current Opinion in Immunology, 2015. 36: p. 54-60.

8. Loo, D.D., et al., Cotransport of water by the $\mathrm{Na}+$ /glucose cotransporter. Proceedings of the National Academy of Sciences of the United States of America, 1996. 93(23): p. 13367-13370.

9. Preston Gregory M., C.T.P., Guggino William B., Agre Peter, Appearance of Water Channels in Xenopus Oocytes Expressing Red Cell CHIP28 Protein. Science, 1992. 256(5055): p. 385-387.

10. M., H.H.T.a.S.W., Osmosis and Solute-Solvent Drag Fluid Transport and Fluid Exchange in Animals and Plants. Cell Biochem Biophys, 2005. 42(3): p. 277-345.

11. Verkman, A., More than just water channels: unexpected cellular roles of aquaporins. Journal of cell science, 2005. 118(Pt 15): p. 3225-3232.

12. Verkman, A.S., Aquaporins in clinical medicine. Annual review of medicine, 2012. 63: p. 303316.

13. Albrecht, S., et al., Role of ion channels and transporters in cell migration. Physiological reviews, 2012. 92(4): p. 1865-1913.

14. Ejaife O. Agbani, B., MSc, PhD; Marion T.J. van den Bosch, BSc, MSc, PhD;, et al., Coordinated Membrane Ballooning and Procoagulant Spreading in Human Platelets. Circulation, 2015. 132(15): p. 1414-24.

15. Karlsson, T., et al., Aquaporin 9 phosphorylation mediates membrane localization and neutrophil polarization. J Leukoc Biol, 2011. 90(5): p. 963-73.

16. Loitto, V.-M.M. and K.-E.E. Magnusson, $\mathrm{Hg} 2+$ and small-sized polyethylene glycols have inverse effects on membrane permeability, while both impair neutrophil cell motility. Biochemical and biophysical research communications, 2004. 316(2): p. 370-378.

17. Karlsson, T., et al., Water fluxes through aquaporin-9 prime epithelial cells for rapid wound healing. Biochemical and biophysical research communications, 2013. 430(3): p. 993-998.

18. Stroka, K.M., et al., Water permeation drives tumor cell migration in confined microenvironments. Cell, 2014. 157(3): p. 611-623.

19. Wu, B., et al., Concerted action of two cation filters in the aquaporin water channel. The EMBO Journal, 2009. 28(15): p. 2188-2194.

20. de Groot, B.L., et al., The Mechanism of Proton Exclusion in the Aquaporin-1 Water Channel. Journal of Molecular Biology, 2003. 333(2): p. 279-293.

21. Itoh, T., et al., Identification of a novel aquaporin, AQP12, expressed in pancreatic acinar cells. Biochemical and biophysical research communications, 2005. 330(3): p. 832-838.

22. Ikeda, M., et al., The NPC Motif of Aquaporin-11, Unlike the NPA Motif of Known Aquaporins, Is Essential for Full Expression of Molecular Function. Journal of Biological Chemistry, 2011. 286(5): p. 3342-3350.

23. Méndez-Giménez, L., et al., Role of aquaglyceroporins and caveolins in energy and metabolic homeostasis. Molecular and Cellular Endocrinology, 2014. 397(1-2): p. 78-92. 
24. Ana, M., F.M. Teresa, and S. Graça, Aquaglyceroporins: implications in adipose biology and obesity. Cellular and Molecular Life Sciences, 2014.

25. Szu, J.I. and D.K. Binder, The Role of Astrocytic Aquaporin-4 in Synaptic Plasticity and Learning and Memory. Frontiers in integrative neuroscience, 2016. 10: p. 8.

26. Manley, G.T., et al., Aquaporin-4 deletion in mice reduces brain edema after acute water intoxication and ischemic stroke. Nature medicine, 2000. 6(2): p. 159-163.

27. Wang, W.-W.W., et al., The function of aquaporin4 in ischemic brain edema. Clinical neurology and neurosurgery, 2014. 127: p. 5-9.

28. Papadopoulos, M.C. and S. Saadoun, Key roles of aquaporins in tumor biology. Biochimica et biophysica acta, 2015. 1848(10 Pt B): p. 2576-2583.

29. Saadoun, S., et al., Impairment of angiogenesis and cell migration by targeted aquaporin-1 gene disruption. Nature, 2005. 434(7034): p. 786-792.

30. Paluch, E. and E. Raz, The role and regulation of blebs in cell migration. Current opinion in cell biology, 2013. 25(5): p. 582-590.

31. Loitto, V.M., et al., Neutrophil leukocyte motility requires directed water influx. J Leukoc Biol, 2002. 71(2): p. 212-22.

32. Jung, H.J., et al., Aquaporin-5: a marker protein for proliferation and migration of human breast cancer cells. PloS one, 2011. 6(12).

33. Chen, J., et al., Aquaporin 3 promotes epithelial-mesenchymal transition in gastric cancer. Journal of experimental \& clinical cancer research : CR, 2014. 33: p. 38.

34. Mukhopadhyay, R., H. Bhattacharjee, and B.P. Rosen, Aquaglyceroporins: Generalized metalloid channels. Biochimica et Biophysica Acta (BBA) - General Subjects, 2014. 1840(5): p. 1583-1591.

35. Carbrey, J.M., et al., Reduced arsenic clearance and increased toxicity in aquaglyceroporin-9null mice. Proceedings of the National Academy of Sciences of the United States of America, 2009. 106(37): p. 15956-15960.

36. Lee, W.-K.K. and F. Thévenod, A role for mitochondrial aquaporins in cellular life-and-death decisions? American journal of physiology. Cell physiology, 2006. 291(2): p. 202.

37. Savage, D.F. and R.M. Stroud, Structural basis of aquaporin inhibition by mercury. J Mol Biol, 2007. 368(3): p. 607-17.

38. Yasui, M., et al., Rapid gating and anion permeability of an intracellular aquaporin. Nature, 1999. 402(6758): p. 184-187.

39. Deziel, E., et al., Analysis of Pseudomonas aeruginosa 4-hydroxy-2-alkylquinolines (HAQs) reveals a role for 4-hydroxy-2-heptylquinoline in cell-to-cell communication. Proc Natl Acad Sci U S A, 2004. 101(5): p. 1339-44.

40. Karlsson, T., et al., Fluxes of water through aquaporin 9 weaken membrane-cytoskeleton anchorage and promote formation of membrane protrusions. PloS one, 2013. 8(4).

41. Martins, A., et al., Targeting aquaporin function: potent inhibition of aquaglyceroporin-3 by a gold-based compound. PloS one, 2012. 7(5).

42. Dorward, H.S., et al., Pharmacological blockade of aquaporin-1 water channel by AqB013 restricts migration and invasiveness of colon cancer cells and prevents endothelial tube formation in vitro. Journal of experimental \& clinical cancer research : CR, 2016. 35(1): p. 36.

43. Conner, A.C., R.M. Bill, and M.T. Conner, An emerging consensus on aquaporin translocation as a regulatory mechanism. Molecular Membrane Biology, 2012. 30(1): p. 101-112.

44. Benga, G., On the definition, nomenclature and classification of water channel proteins (aquaporins and relatives). Molecular aspects of medicine, 2012. 33(5-6): p. 514-517.

45. Tsukaguchi, H., et al., Functional and molecular characterization of the human neutral solute channel aquaporin-9. The American journal of physiology, 1999. 277(5 Pt 2): p. 96.

46. Tsukaguchi, H., et al., Molecular characterization of a broad selectivity neutral solute channel. The Journal of biological chemistry, 1998. 273(38): p. 24737-24743. 
47. Pietrement, C., et al., Role of NHERF1, cystic fibrosis transmembrane conductance regulator, and CAMP in the regulation of aquaporin 9. The Journal of biological chemistry, 2008. 283(5): p. 2986-2996.

48. Karlsson, T., et al., Fluxes of water through aquaporin 9 weaken membrane-cytoskeleton anchorage and promote formation of membrane protrusions. PloS one, 2013. 8(4).

49. Loitto, V., et al., Filopodia are induced by aquaporin-9 expression. Experimental cell research, 2007. 313(7): p. 1295-1306.

50. Mesko, B., et al., Peripheral blood gene expression patterns discriminate among chronic inflammatory diseases and healthy controls and identify novel targets. BMC medical genomics, 2010. 3: p. 15.

51. Oliveira, C.A., et al., Aquaporin-1 and -9 are differentially regulated by oestrogen in the efferent ductule epithelium and initial segment of the epididymis. Biology of the cell / under the auspices of the European Cell Biology Organization, 2005. 97(6): p. 385-395.

52. Yasui, M., et al., Aquaporin-6: An intracellular vesicle water channel protein in renal epithelia. Proc Natl Acad Sci U S A, 1999. 96(10): p. 5808-13.

53. Hazama, A., et al., Ion permeation of AQP6 water channel protein. Single channel recordings after Hg2+ activation. The Journal of biological chemistry, 2002. 277(32): p. 29224-29230.

54. Lee, J.-S.S., et al., Water channels in platelet volume regulation. Journal of cellular and molecular medicine, 2012. 16(4): p. 945-949.

55. Beitz, E., et al., Determinants of AQP6 trafficking to intracellular sites versus the plasma membrane in transfected mammalian cells. Biol Cell, 2006. 98(2): p. 101-9.

56. Nozaki, K., D. Ishii, and K. Ishibashi, Intracellular aquaporins: clues for intracellular water transport? Pflugers Arch, 2008. 456(4): p. 701-7.

57. Enyedi, B., et al., Tissue damage detection by osmotic surveillance. Nature cell biology, 2013. 15(9): p. 1123-1130.

58. Loitto, V.M., T. Karlsson, and K.E. Magnusson, Water flux in cell motility: expanding the mechanisms of membrane protrusion. Cell Motil Cytoskeleton, 2009. 66(5): p. 237-47.

59. Compan, V., et al., Cell volume regulation modulates NLRP3 inflammasome activation. Immunity, 2012. 37(3): p. 487-500.

60. Huttenlocher, A. and A.R. Horwitz, Integrins in cell migration. Cold Spring Harbor perspectives in biology, 2011. 3(9).

61. Lämmermann, T. and M. Sixt, Mechanical modes of 'amoeboid' cell migration. Current opinion in cell biology, 2009. 21(5): p. 636-644.

62. Friedl, P., Prespecification and plasticity: shifting mechanisms of cell migration. Current opinion in cell biology, 2004. 16(1): p. 14-23.

63. Wolf, K., et al., Compensation mechanism in tumor cell migration: mesenchymal-amoeboid transition after blocking of pericellular proteolysis. The Journal of cell biology, 2003. 160(2): p. 267-277.

64. Lämmermann, T. and R.N. Germain, The multiple faces of leukocyte interstitial migration. Seminars in immunopathology, 2014. 36(2): p. 227-251.

65. Heath, J.P., Epithelial cell migration in the intestine. Cell biology international, 1996. 20(2): p. 139-146.

66. Vasioukhin, V. and E. Fuchs, Actin dynamics and cell-cell adhesion in epithelia. Current opinion in cell biology, 2001. 13(1): p. 76-84.

67. Akin, O. and R.D. Mullins, Capping protein increases the rate of actin-based motility by promoting filament nucleation by the Arp2/3 complex. Cell, 2008. 133(5): p. 841-851.

68. Mullins, R.D., J.A. Heuser, and T.D. Pollard, The interaction of Arp2/3 complex with actin: nucleation, high affinity pointed end capping, and formation of branching networks of filaments. Proceedings of the National Academy of Sciences of the United States of America, 1998. 95(11): p. 6181-6186.

69. Schönichen, A. and M. Geyer, Fifteen formins for an actin filament: a molecular view on the regulation of human formins. Biochimica et biophysica acta, 2010. 1803(2): p. 152-163. 
70. Wear, M.A. and J.A. Cooper, Capping protein: new insights into mechanism and regulation. Trends in biochemical sciences, 2004. 29(8): p. 418-428.

71. Adelstein, R.S. and M.A. Conti, Phosphorylation of platelet myosin increases actin-activated myosin ATPase activity. Nature, 1975. 256(5518): p. 597-598.

72. Ridley, A.J. and A. Hall, The small GTP-binding protein rho regulates the assembly of focal adhesions and actin stress fibers in response to growth factors. Cell, 1992. 70(3): p. 389-399.

73. Ridley, A.J., et al., The small GTP-binding protein rac regulates growth factor-induced membrane ruffling. Cell, 1992. 70(3): p. 401-410.

74. Ridley, A.J., Life at the leading edge. Cell, 2011. 145(7): p. 1012-1022.

75. Verkman, A.S., More than just water channels: unexpected cellular roles of aquaporins. J Cell Sci, 2005. 118(Pt 15): p. 3225-32.

76. Loitto, V.M., et al., Filopodia are induced by aquaporin-9 expression. Experimental cell research, 2007. 313(7): p. 1295-1306.

77. Saadoun, S., et al., Impairment of angiogenesis and cell migration by targeted aquaporin-1 gene disruption. Nature, 2005. 434(7034): p. 786-92.

78. Saadoun, S., et al., Involvement of aquaporin-4 in astroglial cell migration and glial scar formation. Journal of cell science, 2005. 118(Pt 24): p. 5691-5698.

79. Monzani, E., et al., AQP1 is not only a water channel: it contributes to cell migration through Lin7/beta-catenin. PloS one, 2009. 4(7).

80. Hara-Chikuma, M. and A.S. Verkman, Aquaporin-3 facilitates epidermal cell migration and proliferation during wound healing. Journal of molecular medicine (Berlin, Germany), 2008. 86(2): p. 221-231.

81. Levin, M.H. and A.S. Verkman, Aquaporin-3-dependent cell migration and proliferation during corneal re-epithelialization. Investigative ophthalmology \& visual science, 2006. 47(10): p. 4365-4372.

82. Thiagarajah, J.R., D. Zhao, and A.S. Verkman, Impaired enterocyte proliferation in aquaporin-3 deficiency in mouse models of colitis. Gut, 2007. 56(11): p. 1529-1535.

83. Bonilla, F.A. and H.C. Oettgen, Adaptive immunity. Journal of Allergy and Clinical Immunology. 125(2): p. S33-S40.

84. Chaplin, D.D., Overview of the immune response. Journal of Allergy and Clinical Immunology, 2010. 125(2).

85. Kurosaki, T., K. Kometani, and W. Ise, Memory B cells. Nat Rev Immunol, 2015. 15(3): p. 149159.

86. Parello, C.S. and E.S. Huseby, Indoctrinating $T$ cells to attack pathogens through homeschooling. Trends in immunology, 2015. 36(6): p. 337-343.

87. $\mathrm{Li}, \mathrm{X}$. and $\mathrm{Y}$. Zheng, Regulatory $T$ cell identity: formation and maintenance. Trends in immunology, 2015. 36(6): p. 344-353.

88. Dunkelberger, J.R. and W.-C. Song, Complement and its role in innate and adaptive immune responses. Cell Research, 2009. 20(1): p. 34-50.

89. Cavaillon, J.-M.M., The historical milestones in the understanding of leukocyte biology initiated by Elie Metchnikoff. Journal of leukocyte biology, 2011. 90(3): p. 413-424.

90. Tauber, A.I., Metchnikoff and the phagocytosis theory. Nature reviews. Molecular cell biology, 2003. 4(11): p. 897-901.

91. Franken, L., M. Schiwon, and C. Kurts, Macrophages: sentinels and regulators of the immune system. Cellular microbiology, 2016. 18(4): p. 475-487.

92. Schulz, C., et al., A lineage of myeloid cells independent of Myb and hematopoietic stem cells. Science (New York, N.Y.), 2012. 336(6077): p. 86-90.

93. Zaidi, M., Skeletal remodeling in health and disease. Nature medicine, 2007. 13(7): p. 791-801.

94. Ren, Y., et al., Immune Evasion Strategies of Pathogens in Macrophages: the Potential for Limiting Pathogen Transmission. Current issues in molecular biology, 2016. 21: p. 21-40.

95. Sica, A., et al., Macrophage polarization in pathology. Cellular and molecular life sciences : CMLS, 2015. 72(21): p. 4111-4126. 
96. Weiss, G. and U.E. Schaible, Macrophage defense mechanisms against intracellular bacteria. Immunological Reviews, 2015. 264(1): p. 182-203.

97. Wittmann, C., et al., Hydrogen peroxide in inflammation: messenger, guide, and assassin. Advances in hematology, 2012. 2012: p. 541471.

98. Tada-Oikawa, S., et al., Generation of hydrogen peroxide precedes loss of mitochondrial membrane potential during DNA alkylation-induced apoptosis. FEBS letters, 1999. 442(1): p. 65-69.

99. Gordon, S., Phagocytosis: An Immunobiologic Process. Immunity, 2016. 44(3): p. 463-475.

100. Kaufmann, S. and A. Dorhoi, Molecular Determinants in Phagocyte-Bacteria Interactions. Immunity, 2016. 44(3): p. 476-491.

101. Moon, C., et al., Aquaporin expression in human lymphocytes and dendritic cells. American journal of hematology, 2004. 75(3): p. 128-133.

102. Ishibashi, K., et al., Cloning and Functional Expression of a New Aquaporin (AQP9) Abundantly Expressed in the Peripheral Leukocytes Permeable to Water and Urea, but Not to Glycerol. Biochemical and Biophysical Research Communications, 1998. 244(1): p. 268-274.

103. Hara-Chikuma, M., et al., Involvement of aquaporin-7 in the cutaneous primary immune response through modulation of antigen uptake and migration in dendritic cells. FASEB journal : official publication of the Federation of American Societies for Experimental Biology, 2012. 26(1): p. 211-218.

104. Hara-Chikuma, M., et al., Chemokine-dependent $T$ cell migration requires aquaporin-3mediated hydrogen peroxide uptake. The Journal of experimental medicine, 2012. 209(10): $p$. 1743-1752.

105. Niethammer, P., et al., A tissue-scale gradient of hydrogen peroxide mediates rapid wound detection in zebrafish. Nature, 2009. 459(7249): p. 996-999.

106. Almasalmeh, A., et al., Structural determinants of the hydrogen peroxide permeability of aquaporins. The FEBS journal, 2014. 281(3): p. 647-656.

107. Hara-Chikuma, M., et al., Aquaporin-3-mediated hydrogen peroxide transport is required for NF-KB signalling in keratinocytes and development of psoriasis. Nature communications, 2015. 6: p. 7454.

108. Miller, E.W., B.C. Dickinson, and C.J. Chang, Aquaporin-3 mediates hydrogen peroxide uptake to regulate downstream intracellular signaling. Proceedings of the National Academy of Sciences of the United States of America, 2010. 107(36): p. 15681-15686.

109. Watanabe, S., et al., Aquaporin-9 facilitates membrane transport of hydrogen peroxide in mammalian cells. Biochemical and biophysical research communications, 2016. 471(1): p. 191197.

110. Pase, L., et al., Neutrophil-delivered myeloperoxidase dampens the hydrogen peroxide burst after tissue wounding in zebrafish. Current biology : CB, 2012. 22(19): p. 1818-1824.

111. Ramachandran, G., Gram-positive and gram-negative bacterial toxins in sepsis: a brief review. Virulence, 2013. 5(1): p. 213-218.

112. Feldman, M., et al., Role of flagella in pathogenesis of Pseudomonas aeruginosa pulmonary infection. Infection and immunity, 1998. 66(1): p. 43-51.

113. COX D. CHARLES, P.J., Use of 2-Aminoacetophenone Production in Identification of Pseudomonas aeruginosa. JOURNAL OF CLINICAL MICROBIOLOGY, 1979. 9(4): p. 479-484.

114. Casadevall, A. and L.a. Pirofski, Host-Pathogen Interactions: The Attributes of Virulence. The Journal of Infectious Diseases, 2001. 184(3): p. 337-344.

115. Gellatly, S.L. and R. Hancock, Pseudomonas aeruginosa: new insights into pathogenesis and host defenses. Pathogens and Disease, 2013. 67(3): p. 159-173.

116. Goehring, U.M., et al., The N-terminal domain of Pseudomonas aeruginosa exoenzyme $S$ is a GTPase-activating protein for Rho GTPases. The Journal of biological chemistry, 1999. 274(51): p. 36369-36372.

117. Kipnis, E., T. Sawa, and J. Wiener-Kronish, Targeting mechanisms of Pseudomonas aeruginosa pathogenesis. Médecine et maladies infectieuses, 2006. 36(2): p. 78-91. 
118. Mathee, K., et al., Mucoid conversion of Pseudomonas aeruginos by hydrogen peroxide: a mechanism for virulence activation in the cystic fibrosis lung. Microbiology, 1999. 145(6): p. 1349-1357.

119. Toder, D.S., et al., lasA and lasB genes of Pseudomonas aeruginosa: analysis of transcription and gene product activity. Infection and immunity, 1994. 62(4): p. 1320-1327.

120. Toder, D.S., M.J. Gambello, and B.H. Iglewski, Pseudomonas aeruginosa LasA: a second elastase under the transcriptional control of lasR. Mol Microbiol, 1991. 5(8): p. 2003-10.

121. Antonio Molinaro, O.H., Flaviana Di Lorenzo, Maire Callaghan, Alessandra Nurisso, Gerardino D’Errico, Alla Zamyatina, Francesco Peri, Rita Berisio, Roman Jerala, Jesus Jimenez-Barbero, Alba Silipo, and Sonsoles Martin-Santamar, Chemistry of Lipid A: At the Heart of Innate Immunity. Chemistry a European Journal, 2015. 21: p. 500 - 519.

122. Schwechheimer, C. and M.J. Kuehn, Outer-membrane vesicles from Gram-negative bacteria: biogenesis and functions. Nature Reviews Microbiology, 2015. 13(10): p. 605-619.

123. Kaparakis-Liaskos, M. and R.L. Ferrero, Immune modulation by bacterial outer membrane vesicles. Nature Reviews Immunology, 2015. 15(6): p. 375-387.

124. Opal, S.M., The host response to endotoxin, antilipopolysaccharide strategies, and the management of severe sepsis. International journal of medical microbiology : IJMM, 2007. 297(5): p. 365-377.

125. Morris, M.C., E.A. Gilliam, and L. Li, Innate Immune Programing by Endotoxin and Its Pathological Consequences. Frontiers in Immunology, 2015. 5.

126. Dinarello, C., Interleukin-1 and interleukin-1 antagonism. Blood, 1991. 77(8): p. 1627-1652.

127. Zanoni, I. and F. Granucci, Differences in lipopolysaccharide-induced signaling between conventional dendritic cells and macrophages. Immunobiology, 2010. 215(9-10): p. 709-712.

128. Talwar, S., et al., Gene expression profiles of peripheral blood leukocytes after endotoxin challenge in humans. Physiological genomics, 2006. 25(2): p. 203-215.

129. Matsushima A, O.H., Koh T, Shimazu T, Sugimoto H. , Enhanced expression of aquaporin 9 in activated polymorphonuclear leukocytes in patients with systemic inflammatory response syndrome. . Shock, 2014. 42(4): p. 322-6.

130. Franck, T., et al., The Gene Expression Analysis of Blood Reveals S100A11 and AQP9 as Potential Biomarkers of Infective Endocarditis. PLoS ONE, 2012. 7(2).

131. Vassiliou, A.G., et al., Induced expression and functional effects of aquaporin-1 in human leukocytes in sepsis. Critical care (London, England), 2013. 17(5).

132. Wang, H., et al., Enhanced expression of aquaporin-9 in rat brain edema induced by bacterial lipopolysaccharides. Journal of Huazhong University of Science and Technology. Medical sciences = Hua zhong ke ji da xue xue bao. Yi xue Ying De wen ban = Huazhong keji daxue xuebao. Yixue Yingdewen ban, 2009. 29(2): p. 150-155.

133. Lehmann, G.L., et al., LPS induces the TNF-alpha-mediated downregulation of rat liver aquaporin-8: role in sepsis-associated cholestasis. American journal of physiology. Gastrointestinal and liver physiology, 2008. 294(2): p. 75.

134. Wang, W., et al., Role of $A Q P 1$ in endotoxemia-induced acute kidney injury. American journal of physiology. Renal physiology, 2008. 294(6): p. 80.

135. de Kievit, T.R., Quorum sensing in Pseudomonas aeruginosa biofilms. Environ Microbiol, 2009. 11(2): p. 279-88.

136. Rutherford, S. and B. Bassler, Bacterial quorum sensing: its role in virulence and possibilities for its control. Cold Spring Harbor perspectives in medicine, 2012. 2(11).

137. Schuster, M., et al., Identification, timing, and signal specificity of Pseudomonas aeruginosa quorum-controlled genes: a transcriptome analysis. J Bacteriol, 2003. 185(7): p. 2066-79.

138. Fazli, M., et al., Regulation of biofilm formation in Pseudomonas and Burkholderia species. Environmental microbiology, 2014. 16(7): p. 1961-1981.

139. Maria Alhede, T.B., Michael Givskov, Morten Alhede Advances in Applied Microbiology "Pseudomonas aeruginosa Biofilms: Mechanisms of Immune Evasion" Vol. 86. 2014: Elsevier. $1-40$. 
140. LaSarre Breah, F.M.J., Exploiting quorum sensing to confuse bacterial pathogens. Microbiology and Molecular Biology Reviews, 2013. 77(1): p. 73-111.

141. Jadhav, G.P., et al., Immunosuppressive but Non-LasR-Inducing Analogues of thePseudomonas aeruginosaQuorum-Sensing MoleculeN-(3-Oxododecanoyl)-I-homoserine Lactone. Journal of Medicinal Chemistry, 2011. 54(9): p. 3348-3359.

142. Chhabra, S.R., et al., Synthetic analogues of the bacterial signal (quorum sensing) molecule N(3-oxododecanoyl)-L-homoserine lactone as immune modulators. Journal of medicinal chemistry, 2003. 46(1): p. 97-104.

143. Murray, E.J., et al., Targeting Staphylococcus aureus Quorum Sensing with Nonpeptidic Small Molecule Inhibitors. Journal of Medicinal Chemistry, 2014. 57(6): p. 2813-2819.

144. Zimmermann, S., et al., Induction of neutrophil chemotaxis by the quorum-sensing molecule N(3-oxododecanoyl)-L-homoserine lactone. Infect Immun, 2006. 74(10): p. 5687-92.

145. Karlsson, T., et al., The Pseudomonas aeruginosa $\mathrm{N}$-acylhomoserine lactone quorum sensing molecules target IQGAP1 and modulate epithelial cell migration. PLoS pathogens, 2012. 8(10).

146. Vikström, E., K.-E.E. Magnusson, and A. Pivoriūnas, The Pseudomonas aeruginosa quorumsensing molecule $\mathrm{N}$-(3-oxododecanoyl)-L-homoserine lactone stimulates phagocytic activity in human macrophages through the p38 MAPK pathway. Microbes and infection / Institut Pasteur, 2005. 7(15): p. 1512-1518.

147. Vikström, E., et al., Role of calcium signalling and phosphorylations in disruption of the epithelial junctions by Pseudomonas aeruginosa quorum sensing molecule. European journal of cell biology, 2010. 89(8): p. 584-597.

148. Shiner, E.K., et al., Pseudomonas aeruginosa autoinducer modulates host cell responses through calcium signalling. Cellular microbiology, 2006. 8(10): p. 1601-1610.

149. Maurer, S., et al., Tasting Pseudomonas aeruginosa Biofilms: Human Neutrophils Express the Bitter Receptor T2R38 as Sensor for the Quorum Sensing Molecule N-(3-Oxododecanoyl)-IHomoserine Lactone. Frontiers in Immunology, 2015. 6.

150. Gaida, M., U. Dapunt, and G. Hänsch, Sensing developing biofilms: the bitter receptor T2R38 on myeloid cells. Pathogens and Disease, 2016. 74(3).

151. Smith, R.S., et al., The Pseudomonas aeruginosa quorum-sensing molecule $\mathrm{N}$-(3oxododecanoyl)homoserine lactone contributes to virulence and induces inflammation in vivo. Journal of bacteriology, 2002. 184(4): p. 1132-1139.

152. Glucksam-Galnoy, Y., et al., The bacterial quorum-sensing signal molecule N-3-oxododecanoyl-L-homoserine lactone reciprocally modulates pro- and anti-inflammatory cytokines in activated macrophages. J Immunol, 2013. 191(1): p. 337-44.

153. Davis, B.M., et al., The interaction of $N$-acylhomoserine lactone quorum sensing signaling molecules with biological membranes: implications for inter-kingdom signaling. PLoS One, 2010. 5(10): p. e13522.

154. Ritchie, A.J., et al., The immunomodulatory Pseudomonas aeruginosa signalling molecule N-(3oxododecanoyl)-L-homoserine lactone enters mammalian cells in an unregulated fashion. Immunol Cell Biol, 2007. 85(8): p. 596-602.

155. Jahoor, A., et al., Peroxisome proliferator-activated receptors mediate host cell proinflammatory responses to Pseudomonas aeruginosa autoinducer. J Bacteriol, 2008. 190(13): p. 4408-15.

156. Cooley, M.A., C. Whittall, and M.S. Rolph, Pseudomonas signal molecule 3-oxo-C12homoserine lactone interferes with binding of rosiglitazone to human PPARgamma. Microbes Infect, 2010. 12(3): p. 231-7.

157. Briggs, M.W. and D.B. Sacks, IQGAP1 as signal integrator: Ca2+, calmodulin, Cdc42 and the cytoskeleton. FEBS Lett, 2003. 542(1-3): p. 7-11.

158. Noritake, J., et al., Positive role of IQGAP1, an effector of Rac1, in actin-meshwork formation at sites of cell-cell contact. Mol Biol Cell, 2004. 15(3): p. 1065-76.

159. Noritake, J., et al., IQGAP1: a key regulator of adhesion and migration. J Cell Sci, 2005. 118(Pt 10): p. 2085-92. 
160. Bensenor, L.B., et al., IQGAP1 regulates cell motility by linking growth factor signaling to actin assembly. J Cell Sci, 2007. 120(Pt 4): p. 658-69.

161. Brandt, D.T. and R. Grosse, Get to grips: steering local actin dynamics with IQGAPs. EMBO Rep, 2007. 8(11): p. 1019-23.

162. Tayler, M.W., Viruses and Man: A History of Interaction. 2014: Springer International Publishing Switzerland.

163. Falsey, A.R., E.E. Walsh, and F.G. Hayden, Rhinovirus and Coronavirus Infection-Associated Hospitalizations among Older Adults. Journal of Infectious Diseases, 2002. 185(9): p. 13381341.

164. Bente, D.A., et al., Crimean-Congo hemorrhagic fever: history, epidemiology, pathogenesis, clinical syndrome and genetic diversity. Antiviral research, 2013. 100(1): p. 159-189.

165. Ergonul, O., Crimean-Congo hemorrhagic fever virus: new outbreaks, new discoveries. Current opinion in virology, 2012. 2(2): p. 215-220.

166. Ergonul, O., Crimean-Congo haemorrhagic fever. Lancet Infect Dis, 2006. 6(4): p. 203-14.

167. Morikawa, S., M. Saijo, and I. Kurane, Recent progress in molecular biology of Crimean-Congo hemorrhagic fever. Comp Immunol Microbiol Infect Dis, 2007. 30(5-6): p. 375-89.

168. Simon, M., C. Johansson, and A. Mirazimi, Crimean-Congo hemorrhagic fever virus entry and replication is clathrin-, $\mathrm{pH}$ - and cholesterol-dependent. J Gen Virol, 2009. 90(Pt 1): p. 210-5.

169. Connolly-Andersen, A.M., K.E. Magnusson, and A. Mirazimi, Basolateral entry and release of Crimean-Congo hemorrhagic fever virus in polarized MDCK-1 cells. J Virol, 2007. 81(5): p. 215864.

170. Simon, M., et al., Microtubule-dependent and microtubule-independent steps in CrimeanCongo hemorrhagic fever virus replication cycle. Virology, 2009. 385(2): p. 313-22.

171. Teijaro, J.R., Type I interferons in viral control and immune regulation. Current Opinion in Virology, 2016. 16: p. 31-40.

172. Hertzog, P.J., L.A. O'Neill, and J.A. Hamilton, The interferon in TLR signaling: more than just antiviral. Trends Immunol, 2003. 24(10): p. 534-9.

173. Stifter, S.A. and C.G. Feng, Interfering with Immunity: Detrimental Role of Type I IFNs during Infection. The Journal of Immunology, 2015. 194(6): p. 2455-2465.

174. Weber, F. and A. Mirazimi, Interferon and cytokine responses to Crimean Congo hemorrhagic fever virus; an emerging and neglected viral zonoosis. Cytokine Growth Factor Rev, 2008. 19(56): p. 395-404.

175. Akinci, E., H. Bodur, and H. Leblebicioglu, Pathogenesis of Crimean-Congo hemorrhagic fever. Vector Borne Zoonotic Dis, 2013. 13(7): p. 429-37.

176. Papa, A., et al., Cytokine levels in Crimean-Congo hemorrhagic fever. J Clin Virol, 2006. 36(4): p. 272-6.

177. Ozturk, B., et al., Evaluation of the association of serum levels of hyaluronic acid, sICAM-1, sVCAM-1, and VEGF-A with mortality and prognosis in patients with Crimean-Congo hemorrhagic fever. J Clin Virol, 2010. 47(2): p. 115-9.

178. Whitehouse, C.A., Crimean-Congo hemorrhagic fever. Antiviral Res, 2004. 64(3): p. 145-60.

179. Dowall, S.D., et al., A Crimean-Congo Haemorrhagic Fever (CCHF) viral vaccine expressing nucleoprotein is immunogenic but fails to confer protection against lethal disease. Hum Vaccin Immunother, 2015: p. 0.

180. Dowall, S.D., et al., Hazara virus infection is lethal for adult type I interferon receptor-knockout mice and may act as a surrogate for infection with the human-pathogenic Crimean-Congo hemorrhagic fever virus. J Gen Virol, 2012. 93(Pt 3): p. 560-4.

181. Rodrigues, S.F. and D.N. Granger, Blood cells and endothelial barrier function. Tissue Barriers, 2015. 3(1-2): p. e978720.

182. Verkman, A.S., M. Hara-Chikuma, and M.C. Papadopoulos, Aquaporins--new players in cancer biology. Journal of molecular medicine (Berlin, Germany), 2008. 86(5): p. 523-529.

183. Karlsson, T., et al., Fluxes of water through aquaporin 9 weaken membrane-cytoskeleton anchorage and promote formation of membrane protrusions. PLoS One, 2013. 8(4): p. e59901. 
184. Holm, A., T. Karlsson, and E. Vikström, Pseudomonas aeruginosa lasl/rhll quorum sensing genes promote phagocytosis and aquaporin 9 redistribution to the leading and trailing regions in macrophages. Frontiers in microbiology, 2015. 6: p. 915.

185. Xian, Z.H., et al., Expression and localization of aquaporin-1 in human cirrhotic liver. Pathol Res Pract, 2009. 205(11): p. 774-80.

186. Towne, J.E., et al., Decreased expression of aquaporin (AQP)1 and AQP5 in mouse lung after acute viral infection. Am J Respir Cell Mol Biol, 2000. 22(1): p. 34-44.

187. Martinez Torres, F.J., et al., Aquaporin 4 regulation during acute and long-term experimental Herpes simplex virus encephalitis. J Neurovirol, 2007. 13(1): p. 38-46.

188. Yang, W. and M.A. McCrae, The molecular biology of rotaviruses X: intercellular dissemination of rotavirus NSP4 requires glycosylation and is mediated by direct cell-cell contact through cytoplasmic extrusions. Archives of virology, 2012. 157(2): p. 305-314.

189. Laforenza, U., Water channel proteins in the gastrointestinal tract. Molecular aspects of medicine, 2012. 33(5-6): p. 642-650.

190. Riegler, G. and I. Esposito, Bristol scale stool form. A still valid help in medical practice and clinical research. Techniques in Coloproctology, 2001. 5(3): p. 163-164.

191. Sugimoto, N., et al., Upregulation of aquaporin expression in the salivary glands of heatacclimated rats. Scientific Reports, 2013. 3: p. 1763.

192. Ishikawa, Y., et al., Water Channels and Zymogen Granules in Salivary Glands. Journal of Pharmacological Sciences, 2006. 100(5): p. 495-512.

193. Delporte, C. and S. Steinfeld, Distribution and roles of aquaporins in salivary glands. Biochimica et Biophysica Acta (BBA) - Biomembranes, 2006. 1758(8): p. 1061-1070.

194. Xu, H., et al., Differential expression of aquaporin-4 in human gastric normal and cancer tissues. Gastroentérologie clinique et biologique, 2009. 33(1 Pt 1): p. 72-76.

195. Mobasheri, A., S. Wray, and D. Marples, Distribution of AQP2 and AQP3 water channels in human tissue microarrays. Journal of molecular histology, 2005. 36(1-2): p. 1-14.

196. Misaka, T., et al., A water channel closely related to rat brain aquaporin 4 is expressed in acidand pepsinogen-secretory cells of human stomach. FEBS letters, 1996. 381(3): p. 208-212.

197. Laforenza, U., et al., Solute transporters and aquaporins are impaired in celiac disease. Biology of the cell / under the auspices of the European Cell Biology Organization, 2010. 102(8): p. 457467.

198. Ishibashi, K., et al., Structure and chromosomal localization of a human water channel (AQP3) gene. Genomics, 1995. 27(2): p. 352-354.

199. Koyama, Y., et al., Expression and localization of aquaporins in rat gastrointestinal tract. The American journal of physiology, 1999. 276(3 Pt 1): p. 7.

200. Itoh, A., et al., Enhancement of aquaporin-3 by vasoactive intestinal polypeptide in a human colonic epithelial cell line. Journal of gastroenterology and hepatology, 2003. 18(2): p. 203-210.

201. Ikarashi, N., et al., Inhibition of aquaporin-3 water channel in the colon induces diarrhea. Biological \& pharmaceutical bulletin, 2012. 35(6): p. 957-962.

202. Bottino, C., et al., Impaired aquaporins expression in the gastrointestinal tract of rat after mercury exposure. Journal of Applied Toxicology, 2016. 36(1): p. 113-120.

203. Wang, K.S., et al., Colon water transport in transgenic mice lacking aquaporin-4 water channels. American journal of physiology. Gastrointestinal and liver physiology, 2000. 279(2): p. 70.

204. Guttman, J.A., et al., Aquaporins contribute to diarrhoea caused by attaching and effacing bacterial pathogens. Cellular Microbiology, 2007. 9(1): p. 131-141.

205. Büsch, K., et al., Nationwide prevalence of inflammatory bowel disease in Sweden: a population-based register study. Alimentary Pharmacology \& Therapeutics, 2014. 39(1): p. 5768.

206. Williams, J.J., et al., Microscopic colitis - a common cause of diarrhoea in older adults. Age and Ageing, 2010. 39(2): p. 162-168. 
207. Münch, A., et al., Microscopic colitis: Current status, present and future challenges: Statements of the European Microscopic Colitis Group. Journal of Crohn's and Colitis, 2012. 6(9).

208. Bjornbak, C., et al., Microscopic colitis: clinical findings, topography and persistence of histopathological subgroups. Aliment Pharmacol Ther, 2011. 34(10): p. 1225-34.

209. Read, N.W., et al., Chronic diarrhea of unknown origin. Gastroenterology, 1980. 78(2): p. 26471.

210. Langner, C., et al., Histology of microscopic colitis-review with a practical approach for pathologists. Histopathology, 2015. 66(5): p. 613-626.

211. Lindström, C., Collagenous colitis with watery diarrhoea - a new entity? . Pathol Eur, 1976. 11: p. 87-9.

212. Farrukh, A. and J.F. Mayberry, Microscopic colitis: a review. Colorectal Disease, 2014. 16(12).

213. Chande, N., J.K. MacDonald, and J.W. McDonald, Interventions for treating microscopic colitis: a Cochrane Inflammatory Bowel Disease and Functional Bowel Disorders Review Group systematic review of randomized trials. Am J Gastroenterol, 2009. 104(1): p. 235-41; quiz 234, 242.

214. Munch, A., et al., Low-dose budesonide for maintenance of clinical remission in collagenous colitis: a randomised, placebo-controlled, 12-month trial. Gut, 2014.

215. Hjortswang, H., et al., Health-related quality of life is impaired in active collagenous colitis. Dig Liver Dis, 2011. 43(2): p. 102-9.

216. Ohlsson, B., New insights and challenges in microscopic colitis. Therapeutic advances in gastroenterology, 2015. 8(1): p. 37-47.

217. Munch, A., et al., Smoking Status Influences Clinical Outcome in Collagenous Colitis. J Crohns Colitis, 2015.

218. Fischer, H., et al., Altered microbiota in microscopic colitis. Gut, 2015. 64(7): p. 1185-1186.

219. Burgel, N., et al., Mechanisms of diarrhea in collagenous colitis. Gastroenterology, 2002. 123(2): p. 433-43.

220. Stampfl, D.A. and L.S. Friedman, Collagenous colitis: pathophysiologic considerations. Dig Dis Sci, 1991. 36(6): p. 705-11.

221. Petr, R., et al., Reduced expression of aquaporins in human intestinal mucosa in early stage inflammatory bowel disease. Clinical and experimental gastroenterology, 2015: p. 49.

222. Hardin, J.A., et al., Aquaporin expression is downregulated in a murine model of colitis and in patients with ulcerative colitis, Crohn's disease and infectious colitis. Cell and tissue research, 2004. 318(2): p. 313-323.

223. Zahn, A., et al., Aquaporin-8 expression is reduced in ileum and induced in colon of patients with ulcerative colitis. World journal of gastroenterology, 2007. 13(11): p. 1687-1695.

224. Holm, A., K.-E. Magnusson, and E. Vikström, Pseudomonas aeruginosa N-3-oxo-dodecanoylhomoserine lactone elicits changes in cell volume, morphology and AQP9 characteristics in macrophages. Frontiers in Cellular and Infection Microbiology, 2016. 6.

225. Vikstrom, E., K.E. Magnusson, and A. Pivoriunas, The Pseudomonas aeruginosa quorumsensing molecule $\mathrm{N}$-(3-oxododecanoyl)-L-homoserine lactone stimulates phagocytic activity in human macrophages through the p38 MAPK pathway. Microbes Infect, 2005. 7(15): p. 15128.

226. Brint, J.M. and D.E. Ohman, Synthesis of multiple exoproducts in Pseudomonas aeruginosa is under the control of RhIR-RhIl, another set of regulators in strain PAO1 with homology to the autoinducer-responsive LuxR-LuxI family. J Bacteriol, 1995. 177(24): p. 7155-63.

227. Pearson, J.P., E.C. Pesci, and B.H. Iglewski, Roles of Pseudomonas aeruginosa las and rhl quorum-sensing systems in control of elastase and rhamnolipid biosynthesis genes. J Bacteriol, 1997. 179(18): p. 5756-67.

228. Winson, M.K., et al., Construction and analysis of luxCDABE-based plasmid sensors for investigating $\mathrm{N}$-acyl homoserine lactone-mediated quorum sensing. FEMS Microbiol Lett, 1998. 163(2): p. 185-92. 
229. Surette, M.G. and B.L. Bassler, Quorum sensing in Escherichia coli and Salmonella typhimurium. Proc Natl Acad Sci U S A, 1998. 95(12): p. 7046-50.

230. Wacker, S.J., et al., The identification of novel, high affinity AQP9 inhibitors in an intracellular binding site. Mol Membr Biol, 2013. 30(3): p. 246-60.

231. Jelen, S., et al., Aquaporin-9 protein is the primary route of hepatocyte glycerol uptake for glycerol gluconeogenesis in mice. J Biol Chem, 2011. 286(52): p. 44319-25.

232. Andersson, I., et al., Role of actin filaments in targeting of Crimean Congo hemorrhagic fever virus nucleocapsid protein to perinuclear regions of mammalian cells. J Med Virol, 2004. 72(1): p. 83-93.

233. Wolf, D.E., The optics of microscope image formation. Methods in cell biology, 2013. 114: p. 11-42.

234. Hoppe, A.D., S. Seveau, and J.A. Swanson, Live cell fluorescence microscopy to study microbial pathogenesis. Cellular microbiology, 2009. 11(4): p. 540-550.

235. Blom, H. and H. Brismar, STED microscopy: increased resolution for medical research? J Intern Med, 2014. 276(6): p. 560-78.

236. Hjortswang, H., et al., Defining clinical criteria for clinical remission and disease activity in collagenous colitis. Inflamm Bowel Dis, 2009. 15(12): p. 1875-81.

237. Vikstrom, E., et al., The junctional integrity of epithelial cells is modulated by Pseudomonas aeruginosa quorum sensing molecule through phosphorylation-dependent mechanisms. Exp Cell Res, 2009. 315(2): p. 313-26.

238. Vikström, E., F. Tafazoli, and K.-E. Magnusson, Pseudomonas aeruginosa quorum sensing molecule $\mathrm{N}$-(3 oxododecanoyl)-I-homoserine lactone disrupts epithelial barrier integrity of Caco-2 cells. FEBS letters, 2006. 580(30): p. 6921-6928.

239. Karlsson, T., et al., $N$-Acylhomoserine lactones are potent neutrophil chemoattractants that act via calcium mobilization and actin remodeling. Journal of leukocyte biology, 2012. 91(1): p. 1526.

240. Wagner, C., et al., The quorum-sensing molecule N-3-oxododecanoyl homoserine lactone (3OC12-HSL) enhances the host defence by activating human polymorphonuclear neutrophils $(P M N)$. Anal Bioanal Chem, 2007. 387(2): p. 481-7.

241. Longo, D.M., et al., Single-Cell Network Profiling of Peripheral Blood Mononuclear Cells from Healthy Donors Reveals Age- and Race-Associated Differences in Immune Signaling Pathway Activation. The Journal of Immunology, 2012. 188(4): p. 1717-1725.

242. Elghetany, T.M. and F. Lacombe, Physiologic variations in granulocytic surface antigen expression: impact of age, gender, pregnancy, race, and stress. Journal of leukocyte biology, 2003. 75(2): p. 157-162.

243. Schorn, C., et al., Sodium overload and water influx activate the NALP3 inflammasome. The Journal of biological chemistry, 2011. 286(1): p. 35-41.

244. Smith, R., et al., The Pseudomonas aeruginosa quorum-sensing molecule $\mathrm{N}$-(3oxododecanoyl)homoserine lactone contributes to virulence and induces inflammation in vivo. Journal of bacteriology, 2002. 184(4): p. 1132-1139.

245. Kosugi-Tanaka, C., et al., Protein kinase A-regulated membrane trafficking of a green fluorescent protein-aquaporin 5 chimera in MDCK cells. Biochim Biophys Acta, 2006. 1763(4): p. 337-44.

246. Honig, J.E., J.C. Osborne, and S.T. Nichol, The high genetic variation of viruses of the genus Nairovirus reflects the diversity of their predominant tick hosts. Virology, 2004. 318(1): p. 106.

247. Lauritzen, G., et al., The $\mathrm{Na}+\mathrm{H}+$ exchanger $\mathrm{NHE1}$, but not the $\mathrm{Na}+\mathrm{HCO}(-)$ cotransporter $N B C n 1$, regulates motility of MCF7 breast cancer cells expressing constitutively active ErbB2. Cancer letters, 2012. 317(2): p. 172-183.

248. Vallés, P.G., et al., Physiological Functions and Regulation of the $\mathrm{Na}+/ \mathrm{H}+$ Exchanger [NHE1] in Renal Tubule Epithelial Cells. Kidney \& blood pressure research, 2015. 40(5): p. 452-466. 
249. Nevoux, J., et al., Glucocorticoids stimulate endolymphatic water reabsorption in inner ear through aquaporin 3 regulation. Pflügers Archiv : European journal of physiology, 2015. 467(9): p. 1931-1943.

250. Andreas, M. and L. Cord, Microscopic Colitis: Clinical and Pathologic Perspectives. Clinical Gastroenterology and Hepatology, 2015. 13(2): p. 228236.

251. Verhaegh B. P. M., d.V.F., Masclee A. A. M., Keshavarzian A., de Boer A., Souverein P. C., Pierik M. J. \& Jonkers D. M. A. E., High risk of drug-induced microscopic colitis with concomitant use of NSAIDs and proton pump inhibitors. Alimentary Pharmacology and Therapeutics, 2016(43): p. 1004-1013.

252. Chen, J.A., et al., Stress alters the expression of aquaporins in cultured rat intestinal epithelial cells. Experimental and Therapeutic Medicine, 2015.

253. Yasui, H., et al., Membrane trafficking of aquaporin 3 induced by epinephrine. Biochemical and biophysical research communications, 2008. 373(4): p. 613-617. 


\section{ACKNOWLEDGEMENTS}

One should be grateful for the journey, for it is said to be life. That is why I'd like to extend my gratitude to the following people, without whom none of this would have been possible.

First I would like to thank my two main supervisors Associate Professor Elena Vikström and Professor Karl-Eric Magnusson. Karl-Eric for letting me into your lab and giving me the opportunity to work in science and pursue my dream of a $\mathrm{PhD}$ and to Elena for taking over the wheel and helping me finish what I started.

To my co-supervisors Vesa Loitto and Jonas Wetterö. Jonas, you have been there from the start, already as a mentor during my master years. You were the one that suggested I'd do a project about aquaporins in Karl-Eric's group, so maybe I can blame you for this! I'm very thankful for all the support and encouragement you have provided me throughout. Vesa for being there, in the background but influencing more than you think. Thanks for all the fun times at conferences all over the states and in Europe. If I have got a scrap of your knowledge of microscopy I will be happy.

To all students and collaborators contributing to this thesis, thank you. I want to give a special thank you to Andreas Münch for giving me the opportunity to work with your patient material, investigating the aquaporin expression.

To all present and former co-workers and colleagues at Medical Microbiology, my daily life would have been nearly impossible and so dull without you.

Till Christina: tack för att du ordnat så mycket fint. Du har verkligen bidragit till varför jag trivts så bra på Medmikro.

Tack Mary för att du har koll på läget och ordnar så bra med allt.

To Andrea; Thank you for all the good times and discussions. It has been very nice to have someone else in the group and to share the aquaporin interest with!

To Thommie Karlsson; "You can observe a lot by watching" you quoted Lawrence (Yogi) Berra in your thesis. I agree. Thank you for your guidance, all the help and inspiration in the beginning of my studies. If I get half as good as you in microscopy, I will be proud. Aquawest for life!

To Johanna Raffetseder; I'm so happy I've found you as a friend and had you as a co-PhD student. You've always been there, thank you for all you help, your scientific input and discussions but first most your friendship.

To Olena; I'm so happy to have you as a friend. Thank you for your support and all the "gossip times".

To Peter, my roommate. Thank you for all the fun times and discussion and your support.

To Kajsa Holmgren Peterson, Tommy Sundqvist and Elisabeth Hollén; thank you for the discussions and support in our lab-meetings and as well as outside of them. 
To all other friends and colleagues at the lab past and present, thank you for making my time here fun and special.

During my time as a PhD student I got the opportunity to be a part of the interdisciplinary research school Forum Scientium. To my friends there, thank you for broaden my scientific knowledge, for discussions and fun times. A special thanks to Stefan Klintström, Charlotte Immerstrand and Anette Andersson, for who without Forum Scientium would not be possible.

To all of my friends:

To new and old PhD student and post-doc friends at Medmikro and elsewhere at the university, past and present, the Innebandy-gang, thank you all for making my time as a $\mathrm{PhD}$ student here fun and manageable.

To my Gun's girls; you are fantastic, Hanna, Pamela, Elin, Klara, Emma and Anna F. Thanks for being there despite long distances in some cases and my lack of ability to stay in close contact. You inspire me to be better and try new things. I love you.

To Jenny, Lina, Anna E and Caroline; thank you for being there and for all the support, discussions and hang outs over fika and dinners.

To my friends outside of research.

Tove for your friendship and your words.

To my dear old friends Emil and Gustaf, thank you for being there even when I haven't been so present in your lives.

To my best and oldest friend in all Evelina Johansson; you once wrote to me "Wiktor Kowalski sa: Att leva är lika viktigt som arkitektur. Kanske till och med viktigare. Det gäller forskning också." Thank you for reminding me. Again and again.

Till min familj; Käraste mamma och pappa, tack för allt ni lärt mig, kärlek, empati och rättvisepatos. Tack för att ni lät mig läsa nästan hur mycket jag ville som barn och tonåring. Tack för att ni alltid funnits och finns där och låter mig gå min egen väg även när ni inte förstår vad jag håller på med eller vad det ska leda till. Till mina kära bröder Mikael, Fredrik och Andreas med familjer, till min kära syster Mikaela; tack för att ni finns där, stöttar mig, tvingar mig försöka förklara vad det egentligen är jag håller på med om och om igen. Tack för att ni alla får mig att byta perspektiv och grundar mig i den verkliga världen. Grundar mig i den jag är. Jag älskar er.

Till Ulf som funnits där genom hela resan. Jag älskar dig. 


\section{Papers}

The articles associated with this thesis have been removed for copyright reasons. For more details about these see:

http://urn.kb.se/resolve?urn=urn:nbn:se:liu:diva-127500 